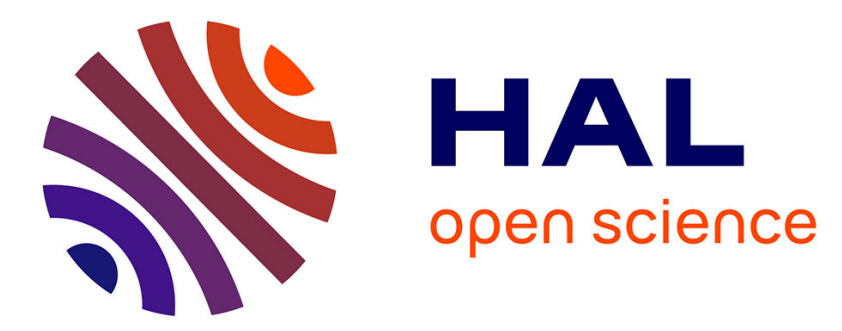

\title{
Factors driving the distribution of an amphibian community in stormwater ponds: a study case in the agricultural plain of Bas-Rhin, France
}

Jonathan Jumeau, Julien Lopez, Alain Morand, Lana Petrod, Françoise Burel, Yves Handrich

\section{To cite this version:}

Jonathan Jumeau, Julien Lopez, Alain Morand, Lana Petrod, Françoise Burel, et al.. Factors driving the distribution of an amphibian community in stormwater ponds: a study case in the agricultural plain of Bas-Rhin, France. European Journal of Wildlife Research, 2020, 66 (2), pp.33. 10.1007/s10344020-1364-5 . hal-02556439

\section{HAL Id: hal-02556439 \\ https://hal.science/hal-02556439}

Submitted on 14 May 2020

HAL is a multi-disciplinary open access archive for the deposit and dissemination of scientific research documents, whether they are published or not. The documents may come from teaching and research institutions in France or abroad, or from public or private research centers.
L'archive ouverte pluridisciplinaire HAL, est destinée au dépôt et à la diffusion de documents scientifiques de niveau recherche, publiés ou non, émanant des établissements d'enseignement et de recherche français ou étrangers, des laboratoires publics ou privés. 
Factors driving the distribution of an amphibian community in stormwater ponds: a study case in the agricultural plain of the Bas-Rhin, France.

Jonathan Jumeau ${ }^{2}$, Julien Lopez ${ }^{2}$, Alain Morand ${ }^{4}$, Lana Petrod ${ }^{2}$, Françoise Burel ${ }^{3}$, Yves Handrich ${ }^{1}$

${ }^{1}$ Université de Strasbourg, CNRS, IPHC UMR 7178, F-67000 Strasbourg, France

${ }^{2}$ Conseil Départemental du Bas-Rhin, Place du Quartier Blanc, 67964 Strasbourg, Cedex 9, France

${ }^{3}$ Université de Rennes 1, CNRS, UMR 6553 ECOBIO, 35042 Rennes Cedex, France

${ }^{4}$ CEREMA, 1 Boulevard Solidarité, 57070 Metz Cedex 3, France

${ }^{\dagger}$ Corresponding author: jumeau.jonathan@gmail.com Tel: (0033)6 076233 63, Postal address: CD67, SPI, Dr. J. Jumeau, Place du Quartier Blanc, 67967, Strasbourg Cedex 9, France. https://orcid.org/0000-0002-6474-3052

Post-Print version

Published online 23 March 2020

European Journal of Wildlife Research

https://doi.org/10.1007/s10344-020-1364-5 
1 Factors driving the distribution of an amphibian community in stormwater ponds: a study case

\section{in the agricultural plain of the Bas-Rhin, France.}

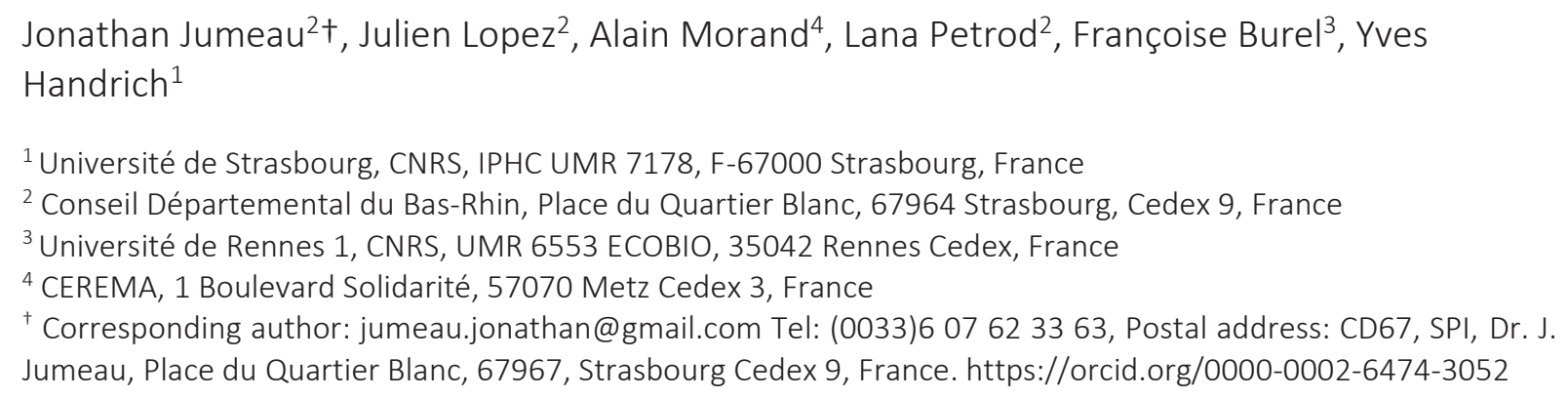

\section{Abstract}

During road construction, stormwater ponds are created to address sanitation, water treatment and the containment of any accidental pollution issues. These environments are not intended to be habitats, so exclosure measures (e.g., fences, barriers...) are implemented to prevent animals to gain access to them. However, the modification of the natural landscape for human needs resulted in the disappearance of most wetlands. Our hypothesis was that depending on the water pollutant concentrations, the stormwater water ponds could serve as refuge habitat for wetlands species like amphibians. Thus, we evaluated the suitability of stormwater ponds as a habitat for amphibians by studying 82 such structures in the agricultural plain of the Bas-Rhin. The proportion of stormwater ponds hosting amphibians and specific species abundances and richness were quantified as community parameters. They were explained using factors such as pond design (e.g., size, depth, slopes...), roadinduced pollutants, land use and exclosures measures. Significance of these factors was assessed by Boosted Regression Tree models. Species dependent effects were studied using detrented correspondence analysis. Amphibians were found in $84 \%$ of stormwater ponds, with an average of 19.51 adults and 2.44 species per pond. We found $83 \%$ of species previously detected in Bas-Rhin, including rare and protected ones. Neither exclosures measures nor pollutants concentration were correlated with community parameters. The best explanatory factors were land use and pond design. For ponds with pollutant concentrations similar to those quantified in this study, we recommend reallocating the efforts made for exclosure to improve pond design and to the creation of seminatural ponds as additional compensatory measures. Design of stormwater ponds should be systematically validated by a herpetologist to avoid mortal traps. Ponds should be large and have a permanent minimum water level even in droughts.

Keywords: refuge habitat, retention ponds, farmlands, semi-natural habitats, modified landscape, pollution 
Behind over-exploitation, agriculture is the next-leading cause of current biodiversity decline and affects all taxonomic groups (Butchart et al., 2010; Maxwell et al., 2016). The habitat loss induced by land consolidation leads to a great number of local population extinctions through the modification of the use and layout of land (Fischer and Lindenmayer, 2007). The creation of vast monocultural farmlands causes the fragmentation of residual semi-natural elements and has negative impacts on species richness, population abundances, growth rate and distribution, trophic chain length, breeding and dispersal success (Benton et al., 2003; Fahrig, 2017). Roads are another cause of biodiversity loss (Forman and Alexander, 1998; Maxwell et al., 2016). Their negative impacts are observed in the road-effect zone and are numerous (Richard et al., 2000; Van Der Ree et al., 2011). For example, roads decrease habitat sizes and quality, affect the life-history traits and population characteristics of species and increase direct and indirect mortality rates (Redon (de) et al., 2015; Spellerberg, 1998). They also contribute to landscape fragmentation through the linearization of landscape (Holderegger and Di Giulio, 2010). These negative effects have numerous adaptations and evolutionary consequences such as changes in vocal pitch and activities in response to traffic noise in birds and amphibians species (Lengagne, 2008; Slabbekoorn and Peet, 2003), higher pollutants tolerance (Brady, 2012), or change of bird wing length in response to roadkill (Brown and Bomberger Brown, 2013; Kiang, 1982). These consequences should be taken into account on impacts studies so that the adaptation would not be underestimated and protection measures would be effective (Brady and Richardson, 2017). Together, intensive agricultural activities and roads form highly modified landscapes in which few natural and semi-natural elements remain, where biodiversity can be very low, and where impacts from both roads and agricultural activities are present (Donald et al., 2001; Foley et al., 2005; Stoate et al., 2001).

Wetlands are particularly impacted by anthropogenic activities like roads and agriculture. At least $64 \%$ of them have disappeared over the past century, and little data is available for the conservation status of what remains. There is a continuing decline of wetlands, accelerated by urban expansion, agricultural intensification, land consolidation and the construction of motorways (Davidson, 2014). Thus, they are internationally protected as they provide important ecosystemic services such as biomass and resource production, pollutant and climate regulation, flood abatement and erosion decrease (Bolund and Hunhammar, 1999; Russi et al., 2013; Zedler, 2003). Moreover, one third of non-marine vertebrate species inhabit wetlands, giving them a high ecological value (Dudgeon et al., 2006). In highly modified landscapes such as farmlands fragmented by roads, wetland 
61 species can survive habitat loss by colonizing the poor quality, isolated remains of semi-natural habitats (McKinney, 2006; Sinsch et al., 2012).

To prevent some of the alteration of aquatic systems, wetlands and other habitats in modified landscapes, artificial ponds called stormwater ponds are built. Located next to roads, urban areas or industrial ones, they are designed to collect, stock and decontaminate runoff otherwise released into a nearby stream. These structures protect outside water from chronic and exceptional contamination (Karouna-Renier and Sparling, 2001; Scher and Thièry, 2005). They also aim to prevent and control flooding events, and to store chenal and canal volume (EPA, 2009). They are required by European legislation for certain surfaces and associated water volumes, and for new or existing infrastructures (Le Viol et al., 2009). There are several types of stormwater ponds (such as micropool, stormwater wetlands...), two of which are retention ponds, which permanently maintain a pool of polluted water throughout the year (permanent hydroperiod), and detention ponds, which hold clean water for a short period of time before it enters the stream (temporary hydroperiod). While detention ponds are usually a simple hole, retention ponds are designed with additional characteristics such as waterflow regulation structures, hydrocarbon separators and waterproof covers (EPA, 2009). Retention ponds can be underground or open-air structures.

Although roads contribute to wetland loss (Van der Ree et al., 2015), amphibian roadkill (Fahrig et al., 1995 ; Elzanowski et al., 2009) and the invasion of non-indigenous species (Jodoin et al., 2008), they may also provide alternative semi-natural habitats for wetlands species. Like natural wetlands, stormwater ponds can provide ecosystem services and are inhabited by flora, birds, invertebrates, snakes and fishes (Ackley and Meylan, 2010; Bishop et al., 2000; Karouna-Renier and Sparling, 2001; Le Viol et al., 2009; Moore and Hunt, 2012). The biodiversity of stormwater ponds can be equivalent to that of semi-natural wetlands (Hassall and Anderson, 2015) and these habitats can be inhabited by rare and protected species (Le Viol et al., 2012). A better understanding of their ecological function on a large scale and in highly modified landscapes is however needed (Brand and Snodgrass, 2010; Scheffers and Paszkowski, 2013). The small number of studies focusing on stormwater pond biodiversity are relatively recent (Bishop et al., 2000). This scarcity of literature could be explained by disinterest of pond managers for stormwater pond biodiversity (Hassall and Anderson, 2015), or by their desire to avoid colonisation by amphibians as stormwater pond water can be polluted (Massal et al., 2007; Snodgrass et al., 2008) and therefore these ponds could be ecological traps (Battin, 2004). Indeed, runoff collected by stormwater ponds can contain agents toxic for aquatic fauna. They contain heavy metals (Wik et al., 2008), polycyclic aromatic hydrocarbons PAHs (Neff et al., 2005) and chlorides (Gallagher et al., 2014). Water 
column pollutants can vary through time, an example being the high increase in chloride concentrations in late winter due to the use of road salt as de-icing agent (Collins and Russell, 2009). Overall pollutant concentrations can quickly increase after storm rainfall on the road surface. However, only a small proportion of these pollutants reaches stormwater ponds as the majority evaporates, stays on road surface, or is degraded by sun exposure (Pagotto, 1999). Pollutant concentration of the sediment is more stable over time, and high concentrations are accumulated, especially if sediment is rarely removed. This can be a non-negligible threat for species that hide or winter in sediment and also for their predators because of the bioaccumulation effect (Bishop et al., 1995; Brand et al., 2010). Concentrations of pollutants can also vary according to the landscape. Maximum threshold levels of nitrites and nitrates from agricultural chemicals can be recorded in highly modified landscapes such as farmlands (Hayes et al., 2006). Thus, despite evidence of the habitat potentiality of stormwater ponds provided by a number of studies (Brown et al., 2012; Scheffers and Paszkowski, 2013), the stormwater ponds could still be ecological traps. Therefore some countries including France demand, at great expense, the installation of exclosure measures such as fences, walls, cattle grids or handrails (Morand and Carsignol, 2019)

Amphibians are wetlands species which can be found in stormwater ponds (McCarthy and Lathrop, 2011; Sievers et al., 2019). One third of them is threatened with extinction all over the world, due to several causes such as diseases and habitat loss (Arntzen et al., 2017; Becker et al., 2007; Dudgeon et al., 2006; Eterovick et al., 2005; Mazerolle et al., 2005). This last threat is particularly serious as the habitat needs of pondbreeding amphibians vary greatly according to the biological traits and biodemographic strategies of each species (Van Buskirk, 2005). Amphibians are also vulnerable to the impact of road traffic due to their immobility facing motor vehicles (Gibbs and Shriver, 2005; Mazerolle et al., 2005) and all their population-scale movements (Joly, 2019). Indeed, the amphibian mass migration concerning most species can reach a distance of $15 \mathrm{~km}$ for anurans and occurs twice a year (Beebee, 1996; Sinsch, 1990). Therefore, it leads amphibians to cross many roads. In highly modified landscapes where only few wetlands remain, it can be difficult for every amphibian species to find suitable ponds (Hamer and McDonnell, 2008). By varying in location, shape, design, function and management, stormwater ponds could serve as alternative habitat for some amphibian species. However, there are very few studies focusing on amphibian community in stormwater ponds. Further research is required to understand the factors, especially pollutants, driving these communities and to find ways of improving the habitat quality of stormwater ponds for amphibians (Brand and Snodgrass, 2010; Scheffers and Paszkowski, 2013; Scher and Thièry, 2005). With sufficient concentration, pollutants can induce sterility and 
121

external and internal abnormalities in amphibians, stunt their growth and increase difficulties during metamorphosis (Bryer et al., 2006; Egea-Serrano et al., 2012; Sievers et al., 2018; Wagner et al., 2014). Concurrently to a bad stormwater pond design which can trap amphibians in dead-end, pollutants could make stormwater ponds ecological traps and therefore toll the bells for these species in modified landscape where few wetlands remain (Clevenot et al., 2018).

\section{Research objectives}

This study focuses on the agricultural plain of the Bas-Rhin (Bas-Rhin: $4755 \mathrm{~km}^{2}, 23$ inhabitants per $\mathrm{km}^{2}$ ), a highly modified landscape composed of vast monoculture areas and roads. We performed a one-breeding season survey of the Anura and Caudata amphibian communities found in stormwater ponds located along public roads with moderate traffic.

Our objectives were to: (1) Qualify and quantify the amphibian community biodiversity and species richness of stormwater ponds, and to; (2) Identify and quantify factors driving the constitution parameters of amphibian communities of stormwater ponds (species and density of population).

We expected that: Firstly, a significant proportion of stormwater ponds hosted amphibians and that inter-species differences existed, following factors like ponds design (size, depth, slopes, etc.) and surrounding land use. Secondly, a negative influence of pollutants, and particularly chlorides, nitrites and nitrates, and no effect of exclosure measures on amphibian communities.

\section{Material and Methods}

3.1. Protocol

\subsubsection{Studied area}

The Department of the Bas-Rhin (Alsace, Grand-Est, France, Fig. 1) has a semi-continental climate with an average temperature of $10.4{ }^{\circ} \mathrm{C}$ and an atmospheric temperature range of $30^{\circ} \mathrm{C}$. The annual precipitation is about $700 \mathrm{~mm}$ per year and the average altitude is $150 \mathrm{~m}$. The road density is $1.9 \mathrm{~km} / \mathrm{km}^{2}$, with more than $3654 \mathrm{~km}$ of public roads with moderate traffic and $240 \mathrm{~km}$ of major roads (mainly private large road with high traffic). In the western part of the Bas-Rhin, a range of low mountains forms the geomorphological unit of the Vosges. Its flora is mainly dominated by Picea, fir, common beech and oak. In the East, the Rhine river is bordered by many wetlands that are certified by the RAMSAR convention ( ${ }^{\circ}$ FR7200025) and protected by the 
Natura 2000 European network $\left(n^{\circ}\right.$ FR4211811, $n^{\circ}$ FR4211810). These wetlands make up less than $1 \%$ of the Bas-Rhin area, the successive building of dykes along the Rhine (1842-1876, 1928-1959) having substantially diminished the area of wetlands in this region. The intensification of agricultural practices also decreased their surfaces through land consolidation. This is illustrated by the courses of the Rhine tributaries from the Vosges, which cross a large agricultural plain landscape that is currently dominated by wheat and maize crops. There is no precise inventory of wetland loss in the Bas-Rhin. On a national scale, France has lost over $67 \%$ of total wetland area since the beginning of the 20th century (Ximenès et al., 2007). The studied area hosts 18 amphibian species.

\subsubsection{Studied ponds}

We monitored 82 of the 84 open-air stormwater ponds of the Bas-Rhin public roads with moderate 158 traffic (Fig. 1), and could not safely access the two remaining ponds. Traffic on those public roads is mainly below 10000 vehicles/day. Stormwater ponds were mainly located in the agricultural plain. Six were located in the Vosges Mountains and only one was in the RAMSAR area near the Rhine (Fig. 1). Stormwater ponds differed substantially in terms of age (from less than one year old to 24), volume (from to 50 to $7000 \mathrm{~m}^{3}$ ) and design (e.g., nature of exclosure measures, type of substrate, angle of banks, etc.). Most (73) were retention ponds (permanent hydroperiod).

\subsubsection{Sampling design}

The presence of amphibians was checked in all the studied stormwater ponds. Three one-night field sessions were carried out for each pond between March and July 2016 to observe early and late-breeding season amphibian species. Field groups included up to ten geographically close ponds. Each pond in a given field group was inspected during the same night. The order in which field groups were checked was randomly chosen during the first field session and replicated in the following sessions.

The sampling protocol was adapted from the "POP Amphibiens communauté" (Barrioz et al., 2016). Sampling began at dusk. For each pond, sampling began by five minutes of listening to estimate the species richness and number of adult males. Visual sampling was then performed with headlamps and flashlights. The sampling was stopped after two patrols around each pond in order to have an equivalent sampling effort between ponds. Indeed, most of them differed substantially in length but only slightly in width. The number of individuals, amplexus, eggs and larvae was noted for each species. The number of floating carcasses and any visible 
morphological abnormalities on adults was also recorded. To avoid any mistakes due to incorrect identification, edible frogs (Pelophylax kl. esculentus), and pool frogs (Pelophylax lessonae) were gathered in a "green frogs" group. We used the Miaud and Muratet, 2004 identification key. The experimental protocol was authorized by the 5/6/2016 nominative authorisation of the French Environmental Code and followed EU Directive 2010/63/EU guidelines for animal experiments.

\subsubsection{Environmental factors}

Several factors were also checked and classified in factor groups (Table 1). Environmental factors (e.g., $\mathrm{pH}$, water and air temperature, visibility, etc) were recorded immediately after samplings for each stormwater pond at every field session. These factors were gathered in the "immediate environmental factors" group. Simultaneously, biological factors were checked (e.g., presence of branches, aquatic plants, fishes, etc.) and gathered in the "biotic factors" group. During the afternoons of the first field session, the stormwater pond characteristics were noted (e.g., nature and state of exclosure measures, nature of substrate, slopes, volume...) and gathered in the "pond design" group. The surface area of landscape elements (e.g., wetlands, crops, forests, etc.) was calculated using GIS with a precision of 1:10 000 (data from CIGAL 2013) in a 500 m-wide buffer ("local-scale group") and $5 \mathrm{~km}$-wide buffer ( "large-scale group") around each stormwater pond (Smith et green 2005). The pollutants of 34 stormwater ponds were quantified between November 2015 and January 2016 in water samples ("water fraction pollutants" group) and sediment ("sediment fraction pollutants" group) collected in the centre of ponds. The entire pollutant sampling protocol was performed by the road maintenance authority as part of its pollutant survey, and was not part of the present study. The set up protocol to collect samples was similar between ponds and pollutants. Samples were always collected after an intense rainy event, with a $10 \mathrm{~L}$ flask, and close to the outlet without precise depth. Samples were individually homogenised without creating vortex inside. The SM Table in Supplementary Materials summarizes the list of the measured pollutants, the methods used, the ISO norms, French legal thresholds (Bas-Rhin, 2008; MEEM, 1998) authorized for stormwater pond outlets, and sublethal thresholds, when available. PH was measured twice: once as part of the water fraction pollutants group, and once for the immediate environmental factors group. Finally, the list and number of species known to be present in the Bas-Rhin and in a $10 \mathrm{~km}$ radius around each stormwater pond was evaluated using a local biodiversity atlas (Odonat, 2017).

\subsection{Methods}

\subsubsection{Objective (1): Qualifying and quantifying amphibian communities}


The global and specific presence (=occurrence), the global and specific abundance of adults and the

amphibian species richness were calculated for each stormwater pond. The global occurrence was set at 1 for a stormwater pond when at least one amphibian adult, larvae, tadpole or egg was found during one of the three field sessions, whatever the species. The specific occurrence was calculated in the same way, but for each species. Specific abundance was defined as the maximal abundance of adult amphibians observed in a stormwater pond among the three field sessions for each species. Global abundance was calculated as the sum of specific abundances. Species richness was defined as the number of different amphibian species observed in one stormwater pond during the three field sessions, whatever the developmental stage of individuals (adult, larvae, tadpole or egg). However, as tadpole, eggs and larvae could be difficult to identify and find for some species, we excluded them from species richness and abundance analysis. Shannon diversity $(H)$ and equitability $\left(\mathrm{E}_{H}\right)$ indices were also calculated (Beals et al., 2000). Descriptive statistics are mean \pm standard error of the mean.

\subsubsection{Objective (2): Identifying factors driving the amphibian community of stormwater ponds}

The global occurrence, global abundance and species richness values of each stormwater pond were used as dependent variables (hereafter referred to as Community Parameters). The factors described in Table $\mathbf{1}$ were used to explain the three dependent variables. A mean of the three field sessions was calculated for the "immediate environmental factors". Measured pollutant concentrations were compared to French legal thresholds and sublethal/lethal thresholds, when available in the literature.

The collinear factors were identified and removed with a stepwise procedure based on the Variance Inflation Factor (significance threshold $=3$ ) and associated with ACP and Spearman tests corrected by Holm's method (Holm, 1979). Factors with insufficient class sample size $(<10)$ were removed from analysis. When possible, different classes were gathered to increase class sample size (Table 1). Boosted regression tree (BRT) models were created (Elith et al., 2008) to explain variations in dependent variables (community parameters: global occurrence, global abundance and species richness). These models do not provide p-values but indicate the relative influence of each factor on explained variation. As suggested by Albeare (2009), the learning rate $L r$ was set to obtain at least 1000 regression trees with a tree complexity of two. To avoid overparameterization, each model created was simplified by using a cross-validation method (dismo package; Elith \& Leathwick, 2017) based on deviance reduction. For each dependant variable, a preliminary model was firstly created for each group of factors (e.g., design, pollutants, etc.). A general model was then created using solely the factors remaining after simplification procedures of preliminary models. Only factors with at least $3 \%$ of relative 
influence and $5 \%$ of summed relative influences were considered significant and retained for analysis and the discussion. For the three final models (one for each dependant variable), the pseudo- $\mathrm{R}^{2}$, called $\mathrm{D}^{2}$, was calculated (Albeare, 2009). To analyse effects per species of these retained factors, a detrented correspondence analysis was performed for each group of factor (vegan and ggord package) using specific abundances. Statistics were performed with R software (v3.3.0) and GIS analysis with QGIS (v2.18.3).

\section{Results}

4.1. Objective (1): Qualifying and quantifying amphibian communities

The presence of amphibians was observed in $69(84 \%)$ of the 82 stormwater ponds. Fourteen species were found (summarized in Figure 2), representing $78 \%$ of the 18 species known in the study area if we consider that the "green frogs" group counted as two species (Odonat, 2017). The four species that were not found were the fire salamander (Salamandra salamandra), the moor frog (Rana arvalis), which has not however been seen in the study area for nine years, the common midwife toad (Alytes obstetricans) and the yellow-bellied toad (Bombina variegata). The species richness of stormwater ponds was $2.44 \pm 0.19$ species (as a reminder, descriptive statistics are "mean \pm standard error of the mean"). We recorded a total of 2046 adults, with an average of $19.51( \pm 3.42)$ adults per stormwater pond. Abundances differed substantially among species (Figure $2492)$

250 Shannon indices and Equitability index were $0.57 \pm 0.06$ and $0.71 \pm 0.03$, respectively.

251 No morphological abnormalities were found on adults. Red fox carcasses were found floating in two stormwater 252 ponds. The first pond had vertical concrete banks and the second had steep banks covered with geomembrane. 253 No service bank or reachable exits were present on the latter, but claw marks were observed on the 254 geomembrane. The month after the study period (August 2016), we observed the death of all the tadpoles in five 255 detention ponds during drought events.

\subsection{Objective (2): Identifying factors driving the amphibian community of stormwater ponds}

The proportion of explained deviance $\mathrm{D}^{2}$ was high for the three $\mathrm{RBT}$ models, one created for each community parameter (global occurrence, global abundance and species richness; Table 2). Chlorides were the only pollutant kept in the statistical BRT model. They had a relative influence of $2.69 \%$ on the global amphibian abundance alone, with a minor negative correlation. No stormwater pond pollutants were above French legal 
thresholds. For sediment pollutants, chromium and PCBs never exceeded thresholds in the ponds studied. For other sediment pollutants, between $23.08 \%$ and $92.31 \%$ of stormwater ponds were above known sub-lethal thresholds. For the water fraction, only Polycyclic Aromatic Hydrocarbons (PAHs) were above known sub-lethal thresholds (17.5\% of stormwater ponds). No characteristic of exclosures measures was correlated with any of the studied community parameters. Fitted functions of each factor with more than $3 \%$ relative influence are presented in Figure 3 (occurrence), Figure 4 (abundance) and Figure 5 (species richness).

Detrented correspondance analysis (results of significant factors per species) show that the age of stormwater ponds was negatively correlated with abundances of the European green toad and green frogs (Figure 6). The presence of many helophytes was negativly correlated with the presence of vegetative fragements in water. The alpine newt abundance was positively correlated with presence of helophytes whereas the agile frog and the marsh frog were negatively correlated with it (Figure 7). The Euopean green toad abundance was positively correlated with $\mathrm{pH}$ and possibly with the water temperature too. Similar but less clear correlations were also found for the march frog and for the smooth newt (Figure 8). At local scale (500 m ; Figure 9), green frogs and the European green toad abundances were positively correlated with surface of annual crops (and also at large scale for green frogs ; Figure 10). The surface of deciduous forest was positively correlated with the smooth newt abundance (Figure 9). At large scale $(5000 \mathrm{~m})$, the European green toad abundance was positively correlated with surface of road and green frogs abundance was also positively correlated with wetlands surface

\section{(Figure 10).}

\section{Discussion}

\subsection{The amphibian communities of stormwater ponds}

As hypothesised, most of the stormwater ponds (84\%) hosted amphibians. This suggests a high attractiveness of stormwater ponds for amphibians, probably driven by necessity as they cannot find suitable ponds (semi-natural or other). The four species that were never observed on these sites (Salamandra salamandra, Rana arvalis, Alytes obstetricans, Bombina variegata) were not expected to be seen in stormwater ponds as they either avoid large ponds and modified landscapes, or are forest species (Räsänen et al., 2003; Vos and Chardon, 1998). A previous study showed that more than a quarter of the total numbers of individuals of the European green toad (Bufotes viridis) in the study area were located in stormwater ponds (Sané and Didier, 2007). Our study shows a similar result, as it was the species with the second highest recorded mean abundances in stormwater ponds. It suggests that stormwater ponds play a crucial role in the conservation of this species, which is strongly protected in this study area. The marsh frog (Pelophylax ridibundus) was also frequently found 
291 in stormwater ponds. Those two species were both pioneer species (Pagano et al., 2001; Sinsch et al., 2007), as

1 observed by Scher and Thièry (2005) in Mediterranean motorway stormwater ponds. If the European green toad tolerates small puddles and gravel pits, the marsh frog needs large ponds, with sufficient depth and high exposure to sunlight (Kuzmin et al., 2009), such as retention stormwater ponds with concrete banks and riprap providing basking sites. The other species, especially newts and those needing more natural conditions, were less abundant. Indeed, even if some stormwater ponds looked like natural ponds with helophytes, clear water, protected species (e.g., odonata, amphibians) and aquatic ecosystems, most (56\%) were vegetation-free with cloudy/turbid water. The number of amphibians found in studied ponds was probably underestimated as we did not adjust numbers according to the species detection probability (Schmidt, 2004). However, the global number of individuals per pond was quite high compared to other ponds in the studied area (2.95 time higher for green toad ; Vacher et al., 2015). Stormwater ponds therefore host high number of adults and species with great interspecies variations in population, as found by Scheffers \& Paszkowski (2013) and Gallagher et al. (2014). Shannon and Equitability values were low, suggesting long-standing populations. This is corroborated by the presence of amphibians in the studied stormwater ponds, whatever the age of the latter. Although our single breeding season observation study leads us to consider stormwater ponds as a real habitat or to have high ecological potentiality in the Bas-Rhin, it is necessary to monitor populations over many years and to do so in other landscapes. Indeed, pollutant-induced genotoxicity could significantly reduce population viability throughout the years (Hamer et al., 2012). This would imply that a suitable stormwater pond can at terms increase the extinction probability although it could contain high amphibian abundances and species richness. An approach based on life-history traits is needed in order to conclude about the potential trap effect of stormwater ponds (Sinsch et al., 2007). This approach should compare at least reproductive success between stormwater ponds and controls. In the current study, we initially wanted to include semi-natural ponds as controls but they were located in too different landscapes associated with other communities, or their number were too low to be significant. Therefore, we can't exclude an ecological trap effect and caution is needed. However, the study highlights the relevance of studying the ecological potentiality of stormwater ponds as they can be the last wetlands remaining in highly modified landscapes.

\subsection{Factors driving the amphibian community of stormwater ponds}

Despite the known negative impacts of pollutants (Brand et al., 2010;Brand \& Snodgrass, 2010; Collins \& Russell, 2009; Gallagher et al., 2014; Karraker, Gibbs, \& Vonesh, 2008), the concentrations observed in this study were probably too low to have a significant effect. Despite our initial hypothesis, no clear evidence was 
321 found of an overall effect of pollutants on amphibian communities at the observed concentrations in stormwater ponds in the Bas-Rhin. This result was supported by the absence of morphological abnormalities. However, the method used in the present study (examination of adult abnormalities) is not as precise as the examination of tadpoles (Wagner et al., 2014). Further experiments should therefore be performed to examine the effect of the observed concentrations of pollutants on amphibian development and reproduction. $\mathrm{pH}$ had the highest relative influence on the studied community parameters (global occurrence, global abundance and species richness), with a negative correlation for $\mathrm{pH}$ values of eight to ten (Fig. 3-5). As only one stormwater pond had an acid water $(<7)$, only the basic effect of $\mathrm{pH}$ was revealed by models. The negative effect of basic $\mathrm{pH}(>7)$ on amphibian communities can be due to herbicides, whose negative effects are amplified in this condition. Moreover, pollutant analysis performed between November 2015 and January 2016 revealed a neutral pH in stormwater ponds. This indicates that $\mathrm{pH}$ became basic during spring, probably due to nitrites from agricultural activities. As these results are based on winter concentrations, the effects of nitrites may be also underestimated. However, detrented correspondence analysis showed a positive relation between $\mathrm{pH}$ and abundance of the European green toad (Fig. 8), which is consistent as the species mainly use ponds in farmlands (Michel et al., 2017 ; also shown here Fig. 9)

Inside the "pond design" group, pond volume was the main predictive factor of amphibian communities. Volumes of less than $1000 \mathrm{~m}^{3}$ had a significant positive linear effect on community parameters. As the depth was not correlated to the volume and was not retained in final models, we suggest that only the surface of stormwater ponds and the perimeter size were of importance for amphibian communities (Guderyahn et al., 2016; Morand and Joly, 1995). There were too few stormwater ponds with volumes of over $1000 \mathrm{~m}^{3}$ to consider any fitted function over this threshold to be significant. Moreover, the effect of volume seems only accurate for global parameters as no specific correlation was observed (Fig. 6). The age of ponds is an interesting factor, as it could reflect the long-term sustainability of amphibian populations. The age of ponds showed no correlation with the presence of most species. However, it did show a reverse relationship with Green frogs and European green toad population (Fig. 6). The main hypothesis is that those two species colonise the stormwater ponds as soon as they are created, inducing a highest population in very young stormwater ponds, maybe decreasing later with the colonization of ponds by helophytes (Fig. 7). In this case, a regular dredging should favour those species.

Until now, stormwater ponds were intended to be unreachable for any species due to the pollutants contained in the water. However, exclosure measures were clearly demonstrated to be ineffective against amphibians. Even the most overprotected stormwater ponds equipped with concrete walls hosted amphibians. Indeed, there are 
many ways to enter stormwater ponds. Amphibians can follow street gutters and fall into the drain network. Depending on the design of the pond, they can also enter via the outlet. Another hypothesis is that birds could carry eggs of amphibian or fish on their legs, but no publication to date validates this popular thought. However, local fishermen indicated us regular observation of Grey heron (Adrea cinerea) drop off in ponds living amphibians and fishes kept in their beak. Eggs may also be involuntarily carried by humans during maintenance process or fishing activities (some stormwater ponds were even used as stock ponds of Northern pike). Poor vegetation maintenance also allows tall grass to grow against the fences and walls, helping amphibians to reach the top. Access can also be gained through large holes left in small fences after careless maintenance work. Finally, fence staples can eventually fall out, creating gaps through which amphibians can pass. If the current exclosure measures cannot keep amphibians out of stormwater ponds, the overprotection of stormwater ponds has to be questioned. The cost of creating completely unreachable stormwater ponds is high. It would require high concrete walls, large cattle grids under portal access, bird netting, fine grids over floor drains and outlets, etc., and would require permanent maintenance to avoid the obstruction of hydraulic pipes and the deterioration of netting. Although creating an underground stormwater pond would be far less expensive, the potential ecological value of stormwater ponds is not to be brushed aside in the current context of modified landscape where the number of semi-natural ponds is limited.

Few biotic and immediate environmental factors (such as temperature or wind during the field sessions) were retained in the final models. Surprisingly, the presence of fish in the ponds had no effect on community parameters (a similar result to Le Viol et al., 2012), despite evidence that the predation by fish negatively affects the occurrence of amphibians (Brown et al., 2012; McCarthy and Lathrop, 2011). It can indicate that amphibian species had not enough evolutionary time to avoid stormwater ponds with higher densities of predators, or that amphibian had no other ponds to go to. Surprisingly, abundances of odonata larvae were positively associated with those of amphibians despite the fact that they are tadpole predators. However, odonata larvae presence could highlight an overall-high water quality leading to higher number of amphibians (Corbet, 1999 in Kalkman et al., 2008).

Abundant aquatic vegetation is known to be positively correlated with amphibian occurrence and species richness (McCarthy and Lathrop, 2011; Shulse et al., 2010; Simon et al., 2009). This was partially confirmed in this study, as the presence of helophytes increased global levels of amphibian abundance. However, high quantities of helophytes slightly decreased the amphibian abundance levels. This may be explained by an observational bias, because of the hard detectability of amphibians among dense vegetation rather than because 
of a real effect of helophytes on the amphibians. A similar effect can probably be observed for algae and vegetative fragments.

As commonly found in the literature, the main factors driving the parameters of amphibian communities were the landscape element factors (Babbitt, Baber, \& Brandt, 2006; Birx-Raybuck et al., 2010; Malmgren, 2002; Pillsbury \& Miller, 2008; Scheffers \& Paszkowski, 2013; Scher \& Thièry, 2005; Sinsch et al., 2012). They alone explained more than half of the observed variations. Some correlations (for example with wetlands, meadows, surrounding species richness and deciduous forests) were self-explanatory given their accordance with the biology of amphibians (Birx-Raybuck et al., 2010; Guderyahn et al., 2016; Le Viol et al., 2012; Simon et al., 2009). One of the main discoveries was the unexpected negative correlation between species richness and stormwater ponds located in intermediary zone between cultivated lands and deciduous forest(Grillet et al., 2015). A shared hypothesis can be made for intermediate areas of annual crops as the same negative correlation was found. In fact, the landscape dynamic of the studied area could be separated into two types of landscape elements (as ponds were never located in cities): annual crops and semi-natural elements mainly composed of forests and wetlands. When the surface of annual crops decreased, the landscape was mainly composed of more natural elements and potentially suitable habitats for amphibians. Thus, the greater number of amphibians could induce a greater number of amphibians in the stormwater ponds. A similar result was observed in newts by Joly et al., 2001. Fewer semi-natural elements were present in the landscape when the surface area of annual crops increased, so stormwater ponds were probably the only suitable habitats for amphibians and were used as refuges (Le Viol et al., 2012, 2009). Another hypothesis could be simply the change in species composition as the Smooth newt was mainly observed in deciduous forests landscape and as Green frogs and the European green toad were mainly found in farmlands (Fig. 9). In this case, it would suggest that an "intermediate" pond could be less efficient to hold large amphibian diversity than fully located in farmland or in deciduous forest ponds. On the other hand, at a local scale, roads were found to have a strong negative effect on amphibians. Although this effect could be due to road pollutants (light, noises, chemicals), we think the barrier effect of road played the biggest role. Indeed, no amphibians were found when ponds were totally surrounded by roads, as reported by Scheffers and Paszkowski (2013) and Parris (2006). However, at large scale, a positive correlation was found between land covered by roads and abundances of European green toad (Fig. 10), possibly due to an higher amount of stormwater ponds (roads or industrial ones).

\subsection{Recommendations}


As exclosure measures are inefficient in preventing stormwater ponds access to amphibians, the time

and financial means dedicated to them should be reallocated to developing a better sediment cleaning process and creating substitute semi-natural ponds that are not connected to road runoff. Observed pollutant concentrations were observed to have no effect on the studied amphibian community parameters (global occurrence, global abundance and species richness) ; it is therefore futile to overprotect stormwater ponds which have real ecological value, but caution is still required. A sensible approach could be to consider all newly constructed stormwater ponds polluted, and remove the exclosure measures once the low pollutant concentrations have been demonstrated. An easier alternative for road managers would be to install efficient exclosure measures or other compensatory measures only if pollutant concentration reached sub-lethal known thresholds after a five-year survey or before this time if very high pollutants concentrations are measured.

The design of stormwater ponds should be systematically validated by an herpetologist to avoid creating potentially mortal traps for animals. For example, the unclimbable banks of two stormwater ponds in this study were traps for mammals and possibly for amphibians too (Chang et al., 2011; Zhang et al., 2010). Exit ladders should be systematically installed. As detention pond water is not permanent, all the tadpoles of these sites can die during droughts (Brand and Snodgrass, 2010; Gallagher et al., 2014). Although some amphibian larvae can accelerate their growth and development in harsh ecosystems, they cannot survive these sudden events, which appear to be more frequent with global warming (Morand et al., 1997; Newman, 1992). We therefore recommend the creation of a permanent minimum water level that can easily be dredged - not only in detention ponds, but also in newly created semi-natural ponds. This extension of the hydroperiod would enhance species occurrences and abundances (Guderyahn et al., 2016).

Other recommendations can be found in Clevenot et al. (2018) about other factors not developed in this study, such as dredging and vegetation maintenance.

\section{Conclusions}

The present study demonstrated a high potential ecological value of stormwater ponds for amphibian communities in the agricultural plain of the Bas-Rhin. Although no pollutant effect was observed on studied community parameters, we cannot unequivocally conclude that pollutants have no effect on the viability of the stormwater ponds amphibian populations and therefore that stormwater ponds are not ecological traps. However, we have demonstrated the ineffectiveness of exclosure measures. In these conditions, we recommend avoiding the installation of costly partitioning measures and reallocating efforts to ecological engineering to create better 
ecological stormwater ponds and more semi-natural ponds in the study area to limit a possible ecological trap effect. Further analysis are needed in other landscapes and over many years to generalise our results.

\section{Acknowledgements}

We thank Margaux Jost, Armando Espinosa and Théo Fort for the help in collecting data. We also thank Pierre Joly, François Guérold, Pauline Jumeau and Éléonore Drais for their input on the manuscript and Joanna Lignot for the English editing.

\section{Author Contributions}

All authors approve this version of the manuscript. They agree to be accountable for the aspects of the work that they conducted, and will ensure that any questions related to the accuracy or integrity of any part of their work are appropriately investigated and resolved. JJ conceived the idea and design methodology; JJ and JL collected the data; JJ and JL carried out data analysis; JJ, YH, AM, LP and FB organised the writing of the manuscript. All authors played an active part in the drafting of the manuscript.

\section{References}

Ackley, J., Meylan, P., 2010. Watersnake eden: use of stormwater retention ponds by mangrove salt marsh snakes (Nerodia clarkii compressicauda) in urban Florida. Herpetol. Conserv. Biol. 5, 17-22.

Albeare, S.M., 2009. Comparisons of Boosted Regression Tree, GLM And GAM Performance In The Standardization Of Yellowfin Tuna Catch-Rate Data From The Gulf Of Mexico Lonline Fishery 85.

Arntzen, J.W., Abrahams, C., Meilink, W.R.M., Iosif, R., Zuiderwijk, A., 2017. Amphibian decline, pond loss and reduced population connectivity under agricultural intensification over a 38 year period. Biodivers. Conserv. 26, 1411-1430. https://doi.org/10.1007/s10531-017-1307-y

Babbitt, K.J., Baber, M.J., Brandt, L.A., 2006. The effect of woodland proximity and wetland characteristics on larval anuran assemblages in an agricultural landscape. Can. J. Zool. 84, 510-519. https://doi.org/10.1139/z06-020

Barrioz, M., Miaud, C., (coord.), 2016. Protocoles de suivi des populations d'amphibiens de France, POPAmphibien.

Bas-Rhin, 2008. Note de Doctrine relative à la gestion des eaux pluviales issues d'une imperméabilisation 
2 3 4

Battin, J., 2004. Bad habitats: Animal ecological traps and the conservation of populations. Soc. Conserv. Biol. 18, 1482-1491. https://doi.org/10.1111/j.1523-1739.2004.00417.x

Beals, M., Gross, L., Harrell, S., 2000. Diversity indices: Shannon's H and E [WWW Document]. URL http://www.tiem.utk.edu/ gross/bioed/bealsmodules/shannonDI.html (accessed 2.2.17).

Becker, C.G., Fonseca, C.R., Haddad, C.F.B., Batista, R.F., Prado, P.I., 2007. Habitat Split and the Global Decline of Amphibians. Science (80-. ). 318, 1775-1777. https://doi.org/10.1126/science.1149374

Beebee, T., 1996. Ecology and Conservation of Amphibians, 1st ed. Chapman \& Hall.

Benton, T.G., Vickery, J.A., Wilson, J.D., 2003. Farmland biodiversity: is habitat heterogeneity the key? Trends Ecol. Evol. 18, 182-188. https://doi.org/10.1016/S0169-5347(03)00011-9

Birx-Raybuck, D.A., Price, S.J., Dorcas, M.E., 2010. Pond age and riparian zone proximity influence anuran occupancy of urban retention ponds. Urban Ecosyst. 13, 181-190. https://doi.org/10.1007/s11252-0090116-9

Bishop, C., Koster, M., Chek, A., Hussell, D., Jock, K., 1995. Chlorinated hydrocarbons and mercury in sediments, Red-winged Blackbirds (Agelaius phoeniceus) and Tree Swallows (Tachycineta bicolour) from wetlands in the Great Lakes-St. Lawrence river basin. Environ. Toxicol. Chem. 14, 491-501.

Bishop, C.A., Struger, J., Barton, D.R., Shirose, L.J., Dunn, L., Lang, A.L., Shepherd, D., 2000. Contamination and wildlife communities in stormwater detention ponds in Guelph and the Greater Toronto Area, Ontario, 1997 and 1998. Part I - Wildlife communities. Water Qual. Res. J. Canada 35, 399-435.

Bolund, P., Hunhammar, S., 1999. Ecosystem services in urban areas. Ecol. Econ. 29, $293-301$. https://doi.org/10.1016/S0921-8009(99)00013-0

Brady, S.P., 2012. Road to evolution? Local adaptation to road adjacency in an amphibian (Ambystoma maculatum). Sci. Rep. 2, 235. https://doi.org/10.1038/srep00235

Brady, S.P., Richardson, J.L., 2017. Road ecology: shifting gears toward evolutionary perspectives. Front. Ecol. Environ. 15, 91-98. https://doi.org/10.1002/fee.1458 
Brand, A., Snodgrass, J.W., 2010. Value of Artificial Habitats for Amphibian Reproduction in Altered Landscapes. Conserv. Biol. 24, 295-301. https://doi.org/10.1111/j.1523-1739.2009.01301.x

Brand, A.B., Snodgrass, J.W., Gallagher, M.T., Casey, R.E., Van Meter, R., 2010. Lethal and sublethal effects of embryonic and larval exposure of Hyla versicolor to stormwater pond sediments. Arch. Environ. Contam. Toxicol. 58, 325-331. https://doi.org/10.1007/s00244-009-9373-0

Brown, C.R., Bomberger Brown, M., 2013. Where has all the road kill gone? Curr. Biol. https://doi.org/10.1016/j.cub.2013.02.023

Brown, D.J., Street, G.M., Nairn, R.W., Forstner, M.R.J., 2012. A place to call home: Amphibian use of created and restored wetlands. Int. J. Ecol. 2012. https://doi.org/10.1155/2012/989872

Bryer, P.J., Elliott, J.N., Willingham, E.J., 2006. The effects of coal tar based pavement sealer on amphibian development and metamorphosis. Ecotoxicology 15, 241-247. https://doi.org/10.1007/s10646-005-0055-Z

Butchart, S.H.M., Walpole, M., Collen, B., van Strien, A., Scharlemann, J.P.W., Almond, R.E.A., Baillie, J.E.M., Bomhard, B., Brown, C., Bruno, J., Carpenter, K.E., Carr, G.M., Chanson, J., Chenery, A.M., Csirke, J., Davidson, N.C., Dentener, F., Foster, M., Galli, A., Galloway, J.N., Genovesi, P., Gregory, R.D., Hockings, M., Kapos, V., Lamarque, J.-F., Leverington, F., Loh, J., McGeoch, M.A., McRae, L., Minasyan, A., Morcillo, M.H., Oldfield, T.E.E., Pauly, D., Quader, S., Revenga, C., Sauer, J.R., Skolnik, B., Spear, D., Stanwell-Smith, D., Stuart, S.N., Symes, A., Tierney, M., Tyrrell, T.D., Vie, J.-C., Watson, R., 2010. Global Biodiversity: Indicators of Recent Declines. Science (80-. ). 328, 1164-1168. https://doi.org/10.1126/science. 1187512

Chang, Y.-H., Wang, H.-W., Hou, W.-S., 2011. Effects of construction materials and design of lake and stream banks on climbing ability of frogs and salamanders. Ecol. Eng. 37, 1726-1733. https://doi.org/10.1016/j.ecoleng.2011.07.005

CIGAL, 2013. Données faune Alsace [WWW Document]. Coopération pour l'information géographique en Alsace. URL https://www.cigalsace.org/portail/

514 Clevenot, L., Carré, C., Pech, P., 2018. A Review of the Factors That Determine Whether Stormwater Ponds Are Ecological Traps And/or High-Quality Breeding Sites for Amphibians. Front. Ecol. Evol. 6. https://doi.org/10.3389/fevo.2018.00040 
517 Collins, S.J., Russell, R.W., 2009. Toxicity of road salt to Nova Scotia amphibians. Environ. Pollut. 157, $320-4$. https://doi.org/10.1016/j.envpol.2008.06.032

Corbet, P.S., 1999. Dragonflies: behaviour and ecology of Odonata., Dragonflies: behaviour and ecology of Odonata. Harley Books.

Davidson, N.C., 2014. How much wetland has the world lost? Long-term and recent trends in global wetland area. Mar. Freshw. Res. 65, 934. https://doi.org/10.1071/MF14173

Donald, P., Green, R., Heath, M., 2001. Agricultural intensification and the collapse of Europe's farmland bird populations. Proc. ot R. Soc. B-Biological Sci. 268, 25-29.

Dudgeon, D., Arthington, A.H., Gessner, M.O., Kawabata, Z.-I., Knowler, D.J., Lévêque, C., Naiman, R.J., Prieur-Richard, A.-H., Soto, D., Stiassny, M.L.J., Sullivan, C.A., 2006. Freshwater biodiversity: importance, threats, status and conservation challenges. Biol. Rev. 81, 163. https://doi.org/10.1017/S1464793105006950

Egea-Serrano, A., Relyea, R.A., Tejedo, M., Torralva, M., 2012. Understanding of the impact of chemicals on amphibians: A meta-analytic review. Ecol. Evol. 2, 1382-1397. https://doi.org/10.1002/ece3.249

Elith, J., Leathwick, J.R., 2017. Boosted regression trees for ecological modeling. https://doi.org/10.1890/00129658(2007)88[243:BTFEMA]2.0.CO;2

Elith, J., Leathwick, J.R., Hastie, T., 2008. A working guide to boosted regression trees. J. Anim. Ecol. 77, 802813. https://doi.org/10.1111/j.1365-2656.2008.01390.x

EPA Environmental protection agency, 2009. Stormwater wet pond and wetland management guidebook.

Eterovick, P.C., de Queiroz Carnaval, A.C.O., Borges-Nojosa, D.M., Silvano, D.L., Segalla, M.V., Sazima, I., 2005. Amphibian Declines in Brazil: An Overview1. Biotropica 37, 166-179. https://doi.org/10.1111/j.1744-7429.2005.00024.x

Fahrig, L., 2017. Ecological responses to habitat fragmentation per se. Annu. Rev. Ecol. Evol. Syst. 48, 1-23. https://doi.org/https://doi.org/10.1146/annurev-ecolsys-110316-022612

Fahrig, L., Pedlar, J.H., Pope, S.E., Taylor, P.D., Wegner, J.F., 1995. Effect of road traffic on amphibian density. Biol. Conserv. 73, 177-182. https://doi.org/10.1016/0006-3207(94)00102-V 
543 Fischer, J., Lindenmayer, D.B., 2007. Landscape modification and habitat fragmentation: a synthesis. Glob.

Foley, J.A., Defries, R., Asner, G.P., Barford, C., Bonan, G., Carpenter, S.R., Chapin, F.S., Coe, M.T., Daily, G.C., Gibbs, H.K., Helkowski, J.H., Holloway, T., Howard, E.A., Kucharik, C.J., Monfreda, C., Patz, J.A., Prentice, I.C., Ramankutty, N., Snyder, P.K., 2005. Global consequences of land use. Science (80-. ). 309, 570-4. https://doi.org/10.1126/science. 1111772

Forman, R.T.T., Alexander, L.E., 1998. Roads and their major ecological effects. Annu. Rev. Ecol. Syst. 29, 207-231. https://doi.org/10.1146/annurev.ecolsys.29.1.207

Gallagher, M.T., Snodgrass, J.W., Brand, A.B., Casey, R.E., Lev, S.M., Van Meter, R.J., 2014. The role of pollutant accumulation in determining the use of stormwater ponds by amphibians. Wetl. Ecol. Manag. 551-564. https://doi.org/10.1007/s11273-014-9351-9

Gibbs, J.P., Shriver, W.G., 2005. Can road mortality limit populations of pool-breeding amphibians? Wetl. Ecol. Manag. 13, 281-289. https://doi.org/10.1007/s11273-004-7522-9

Grillet, P., Lourdais, O., Boissinot, A., Besnard, A., 2015. Small woods positively influence the occurrence and abundance of the common frog (Rana temporaria) in a traditional farming landscape. Amphibia-Reptilia 36, 417-424. https://doi.org/10.1163/15685381-00003013

Guderyahn, L.B., Smithers, A.P., Mims, M.C., 2016. Assessing habitat requirements of pond-breeding amphibians in a highly urbanized landscape: implications for management. Urban Ecosyst. 19, 1801-1821. https://doi.org/10.1007/s11252-016-0569-6

Hamer, A.J., McDonnell, M.J., 2008. Amphibian ecology and conservation in the urbanising world: A review. Biol. Conserv. 141, 2432-2449. https://doi.org/10.1016/j.biocon.2008.07.020

Hamer, A.J., Smith, P.J., McDonnell, M.J., 2012. The importance of habitat design and aquatic connectivity in amphibian use of urban stormwater retention ponds. Urban Ecosyst. 15, 451-471. https://doi.org/10.1007/s11252-011-0212-5

Hassall, C., Anderson, S., 2015. Stormwater ponds can contain comparable biodiversity to unmanaged wetlands in urban areas. Hydrobiologia 745, 137-149. https://doi.org/10.1007/s10750-014-2100-5 
Hayes, T.B., Case, P., Chui, S., Chung, D., Haeffele, C., Haston, K., Lee, M., Mai, V.P., Marjuoa, Y., Parker, J., Tsui, M., 2006. Pesticide Mixtures, Endocrine Disruption, and Amphibian Declines: Are We Underestimating the Impact? Environ. Health Perspect. 114, 40-50. https://doi.org/10.1289/ehp.8051

Holderegger, R., Di Giulio, M., 2010. The genetic effects of roads: A review of empirical evidence. Basic Appl. Ecol. 11, 522-531. https://doi.org/10.1016/j.baae.2010.06.006

Holm, S., 1979. A simple sequentially rejective multiple test procedure. Scand. J. Stat. 6, 65-70.

Jodoin, Y., Lavoie, C., Villeneuve, P., Theriault, M., Beaulieu, J., Belzile, F., 2008. Highways as corridors and habitats for the invasive common reed Phragmites australis in Quebec, Canada. J. Appl. Ecol. 45, 459466. https://doi.org/10.1111/j.1365-2664.2007.01362.x

Joly, P., 2019. Behavior in a Changing Landscape: Using Movement Ecology to Inform the Conservation of Pond-Breeding Amphibians. Front. Ecol. Evol. 7, 155. https://doi.org/10.3389/fevo.2019.00155

Joly, P., Miaud, C., Lehmann, A., Grolet, O., 2001. Habitat Matrix Effects on Pond Occupancy in Newts. Conserv. Biol. 15, 239-248. https://doi.org/10.1046/j.1523-1739.2001.99200.x

Kalkman, V.J., Clausnitzer, V., Dijkstra, K.-D.B., Orr, A.G., Paulson, D.R., van Tol, J., 2008. Global diversity of dragonflies (Odonata) in freshwater. Hydrobiologia 595, 351-363. https://doi.org/10.1007/s10750-0079029-X

Karouna-Renier, N.K., Sparling, D.W., 2001. Relationships between ambient geochemistry, watershed land-use and trace metal concentrations in aquatic invertebrates living in stormwater treatment ponds. Environ. Pollut. 112, 183-192. https://doi.org/10.1016/S0269-7491(00)00119-6

Karraker, N.E., Gibbs, J.P., Vonesh, J.R., 2008. Impacts of Road Deicing Salt on the Demography of Vernal Pool-Breeding Amphibians. Ecol. Appl. 18, 724-734. https://doi.org/10.1890/07-1644.1

Kiang, Y.T., 1982. Local Differentiation of Anthoxanthum odoratum L. Populations on Roadsides. Am. Midl. Nat. 107, 340. https://doi.org/10.2307/2425384

Kuzmin, S., Tarkhnishvili, D., Ishchenko, V., Dujsebayeva, T., Tuniyev, B., Papenfuss, T., Beebee, T., Ugurtas, I.H., Sparreboom, M., Rastegar-Pouyani, N., Disi, A.M.M., Anderson, S., Denoël, M., Andreone, F., 2009. Pelophylax ridibundus, Eurasian Marsh Frog. IUCN Red List Threat. Species 2009 e.T58705A11825745 
8235.

Le Viol, I., Chiron, F., Julliard, R., Kerbiriou, C., 2012. More amphibians than expected in highway stormwater ponds. Ecol. Eng. 47, 146-154. https://doi.org/10.1016/j.ecoleng.2012.06.031

Le Viol, I., Mocq, J., Julliard, R., Kerbiriou, C., 2009. The contribution of motorway stormwater retention ponds to the biodiversity of aquatic macroinvertebrates. Biol. Conserv. 142, 3163-3171. https://doi.org/10.1016/j.biocon.2009.08.018

Lengagne, T., 2008. Traffic noise affects communication behaviour in a breeding anuran, Hyla arborea. Biol. Conserv. 141, 2023-2031. https://doi.org/10.1016/j.biocon.2008.05.017

Malmgren, J.C., 2002. How does a newt find its way from a pond? Migration patterns after breeding and metamorphosis in great crested newts (Triturus cristatus) and smooth newts (T. vulgaris). Herpetol. J. 12, 29-35.

Massal, L.R., Snodgrass, J.W., Casey, R.E., 2007. Nitrogen pollution of stormwater ponds: Potential for toxic effects on amphibian embryos and larvae. Appl. Herpetol. 4, 19-29.

Maxwell, S.L., Fuller, R.A., Brooks, T.M., Watson, J.E.M., 2016. The ravages of guns, nets and bulldozers. Nature 536, 146-145. https://doi.org/10.1038/536143a

Mazerolle, M.J., Huot, M., Gravel, M., 2005. Behavior of amphibians on the road in response to car traffic. Herpetologica 61, 380-388. https://doi.org/10.1655/04-79.1

McCarthy, K., Lathrop, R.G., 2011. Stormwater basins of the New Jersey coastal plain: Subsidies or sinks for frogs and toads? Urban Ecosyst. 14, 395-413. https://doi.org/10.1007/s11252-011-0161-z

McKinney, M.L., 2006. Urbanization as a major cause of biotic homogenization. Biol. Conserv. 127, $247-260$. https://doi.org/10.1016/j.biocon.2005.09.005

MEEM, 1998. Arrêté du 8 janvier 1998 fixant les prescriptions techniques applicables aux épandages de boues sur les sols agricoles pris en application du décret n ${ }^{\circ} 97-1133$ du 8 décembre 1997 relatif à l'épandage des boues issues du traitement des eaux usées, Jo.

619 Miaud, C., Muratet, J., 2004. Identifier les oeufs et les larves des amphibiens de France, 1st ed. Broché. 
620 Michel, V., Gosselin, F., Fizesan, A., 2017. Convention pluriannuelle d'objectifs : Suivi des populations de crapaud vert, Bufotes viridis (Laurenti, 1768) dans le Bas-Rhin.

Moore, T.L.C., Hunt, W.F., 2012. Ecosystem service provision by stormwater wetlands and ponds - A means for evaluation? Water Res. 46, 6811-6823. https://doi.org/10.1016/j.watres.2011.11.026

Morand, A., Carsignol, J., 2019. Amphibiens et dispositifs de franchissement des infrastructures de transport terrestre.

Morand, A., Joly, P., 1995. Habitat variability and space utilization by the amphibian communities of the French upper-rhone floodplain. Hydrobiologia 300-301, 249-257. https://doi.org/10.1007/BF00024465

Morand, A., Joly, P., Grolet, O., 1997. Phenotypic variation in metamorphosis in five anuran species along a gradient of stream influence. Comptes Rendus l'Académie des Sci. - Ser. III - Sci. la Vie 320, 645-652. https://doi.org/10.1016/S0764-4469(97)85698-3

Neff, J.M., Stout, S.A., Gunster, D.G., 2005. Ecological Risk Assessment of Polycyclic Aromatic Hydrocarbons in Sediments: Identifying Sources and Ecological Hazard. Integr. Environ. Assess. Manag. 1, 22. https://doi.org/10.1897/IEAM_2004a-016.1

Newman, R., 1992. Adaptative plasticity in amphibian metamorphosis. BioSc 42, 671-678.

Odonat: Office des données naturalistes du Grand-Est, 2017. Atlas des espèces d'Alsace [WWW Document].

Pagano, A., Crochet, P.A., Graf, J.-D., Joly, P., Lode, T., 2001. Distribution and habitat use of water frog hybrid complexes in France. Glob. Ecol. Biogeogr. 10, 433-441. https://doi.org/10.1046/j.1466822X.2001.00246.X

Pagotto, C., 1999. Etude sur l'émission et le transfert dans les eaux et les sols des éléments-trace métalliques et des hydrocarbures en domaine routier. Université de Poitiers.

Parris, K.M., 2006. Urban amphibian assemblages as metacommunities. J. Anim. Ecol. 75, 757-764. https://doi.org/10.1111/j.1365-2656.2006.01096.x

Pillsbury, F.C., Miller, J.R., 2008. Habitat and landscape characteristics underlying anuran community structure along an urban-rural gradient. Ecol. Appl. 18, 1107-1118. https://doi.org/10.1890/07-1899.1 
Räsänen, K., Laurila, A., Merilä, J., 2003. Geographic variation in acide stress tolerance of the moor frog Rana arvalis I. Local adaptation. Evolution (N. Y). 57, 352. https://doi.org/10.1554/00143820(2003)057[0352:GVIAST]2.0.CO;2

Redon (de), L., Le Viol, I., Jiguet, F., Machon, N., Scher, O., Kerbiriou, C., 2015. Road network in an agrarian landscape: Potential habitat, corridor or barrier for small mammals? Acta Oecologica 62, 58-65. https://doi.org/10.1016/j.actao.2014.12.003

Richard, T., Forman, T., Deblinger, R.D., 2000. The ecological road-effect zone of a Massachusetts (U.S.A.) suburban highway. Conserv. Biol. 14, 36-46. https://doi.org/10.1046/j.1523-1739.2000.99088.x

Russi, D., ten Brik, P., Farmer, A., Badura, T., Coates, D., Förster, J., Kumar, R., Davidson, N., 2013. The economics of ecosystems and biodiversity for water and wetlands. IEEP, London and Brussels; Ramsar Secretariat, Gland.

Sané, F., Didier, S., 2007. Typologie des sites de reproduction du crapaud vert (Bufo viridis Laurenti, 1768) en Alsace. Ciconia 31, 19-28.

Scheffers, B.R., Paszkowski, C.A., 2013. Amphibian use of urban stormwater wetlands: The role of natural habitat features. Landsc. Urban Plan. 113, 139-149. https://doi.org/10.1016/j.landurbplan.2013.01.001

Scher, O., Thièry, A., 2005. Odonata, Amphibia and environmental characteristics in motorway stormwater retention ponds (Southern France). Hydrobiologia 551, 237-251. https://doi.org/10.1007/s10750-0054464-Z

Schmidt, B.R., 2004. Declining amphibian populations: The pitfalls of count data in the study of diversity, disributions, dynamics, and demography. Herpetol. J. 14, 167-174. https://doi.org/10.5167/uzh-58012

Shulse, C.D., Semlitsch, R.D., Trauth, K.M., Williams, A.D., 2010. Influences of Design and Landscape Placement Parameters on Amphibian Abundance in Constructed Wetlands. Wetlands 30, 915-928. https://doi.org/10.1007/s13157-010-0069-z

Sievers, M., Hale, R., Swearer, S.E., Parris, K.M., 2019. Frog occupancy of polluted wetlands in urban landscapes. Conserv. Biol. 33, 389-402. https://doi.org/10.1111/cobi.13210

Sievers, M., Parris, K.M., Swearer, S.E., Hale, R., 2018. Stormwater wetlands can function as ecological traps 
Simon, J.A., Snodgrass, J.W., Casey, R.E., Sparling, D.W., 2009. Spatial correlates of amphibian use of constructed wetlands in an urban landscape. Landsc. Ecol. 24, 361-373. https://doi.org/10.1007/s10980008-9311-y

Sinsch, U., 1990. Migration And Orientation In Anuran Amphibians. Ethol. Ecol. Evol. - ETHOL ECOL EVOL 2, 65-79. https://doi.org/10.1080/08927014.1990.9525494

Sinsch, U., Leskovar, C., Drobig, A., König, A., Grosse, W.-R., 2007. Life-history traits in green toad ( Bufo viridis ) populations: indicators of habitat quality. Can. J. Zool. 85, 665-673. https://doi.org/10.1139/Z07046

Sinsch, U., Oromi, N., Miaud, C., Denton, J., Sanuy, D., 2012. Connectivity of local amphibian populations: Modelling the migratory capacity of radio-tracked natterjack toads. Anim. Conserv. 15, 388-396. https://doi.org/10.1111/j.1469-1795.2012.00527.x

Slabbekoorn, H., Peet, M., 2003. Birds sing at a higher pitch in urban noise. Nature 424, 267-267. https://doi.org/10.1038/424267a

Snodgrass, J.W., Casey, R.E., Joseph, D., Simon, J.A., 2008. Microcosm investigations of stormwater pond sediment toxicity to embryonic and larval amphibians: Variation in sensitivity among species. Environ. Pollut. 154, 291-297. https://doi.org/10.1016/j.envpol.2007.10.003

Spellerberg, I., 1998. Ecological effects of roads and traffic : a literature review. Glob. Ecol. Biogeogr. Lett. 7, $317-333$

Stoate, C., Boatman, N.., Borralho, R.., Carvalho, C.R., Snoo, G.R. d., Eden, P., 2001. Ecological impacts of arable intensification in Europe. J. Environ. Manage. 63, 337-365. https://doi.org/10.1006/jema.2001.0473

Vacher, J., Michel, V., Fizesan, A., Thiriet, J., Zrak, E., Gosselin, F., 2015. Bilan de dix années de suivi des indicateurs de la biodiversité en Alsace. Richesse et diversté spécifiques des communautés d'amphibiens au sein d'un réseau de mares. Ciconia 39, 128-136.

Van Buskirk, J., 2005. Local and landscape influence on amphibian occurence and abundance. Ecology 86, 1936-1947. https://doi.org/10.1890/04-1237 
Van Der Ree, R., Jaeger, J.A.G., Van Der Grift, E.A., Clevenger, A.P., 2011. Effects of roads and traffic on wildlife populations and landscape function : Road Ecology is moving toward larger scales. Ecol. Soc. 16, 48.

Van der Ree, R., Smith, J., Grilo, C., 2015. The ecological effects of linear infrastructure and traffic: challenges and opportunities of rapid global growth, in: Handbook of Road Ecology. pp. 1-9.

Vos, C., Chardon, J., 1998. Effects of habitat fragmentation and road density on the distribution pattern of the moor frog Rana arvalis. J. Appl. Ecol. 35, 44-56.

Wagner, N., Züghart, W., Mingo, V., Lötters, S., 2014. Are deformation rates of anuran developmental stages suitable indicators for environmental pollution? Possibilities and limitations. Ecol. Indic. 45, 394-401. https://doi.org/10.1016/j.ecolind.2014.04.039

Wik, A., Lycken, J., Dave, G., 2008. Sediment Quality Assessment of Road Runoff Detention Systems in Sweden and the Potential Contribution of Tire Wear. Water. Air. Soil Pollut. 194, 301-314. https://doi.org/10.1007/s11270-008-9718-8

Ximenès, M., Fouque, C., Barnaud, G., 2007. Etat 2000 et évolution 1990-2000 des zones humides d' importance majeure, Document technique IFEN-ONCFS-MNHN-FNC.

Zedler, J.B., 2003. Wetlands at your service: reducing impacts of agriculture at the watershed scale. Front. Ecol. Environ. 1, 65-72. https://doi.org/10.1890/1540-9295(2003)001[0065:WAYSRI]2.0.CO;2

714 Zhang, Z., Yang, H., Yang, H., Li, Y., Wang, T., 2010. The impact of roadside ditches on juvenile and sub-adult 715 Bufo melanostictus migration. Ecol. Eng. 36, 1242-1250. https://doi.org/10.1016/j.ecoleng.2010.04.025 


\section{Figures}

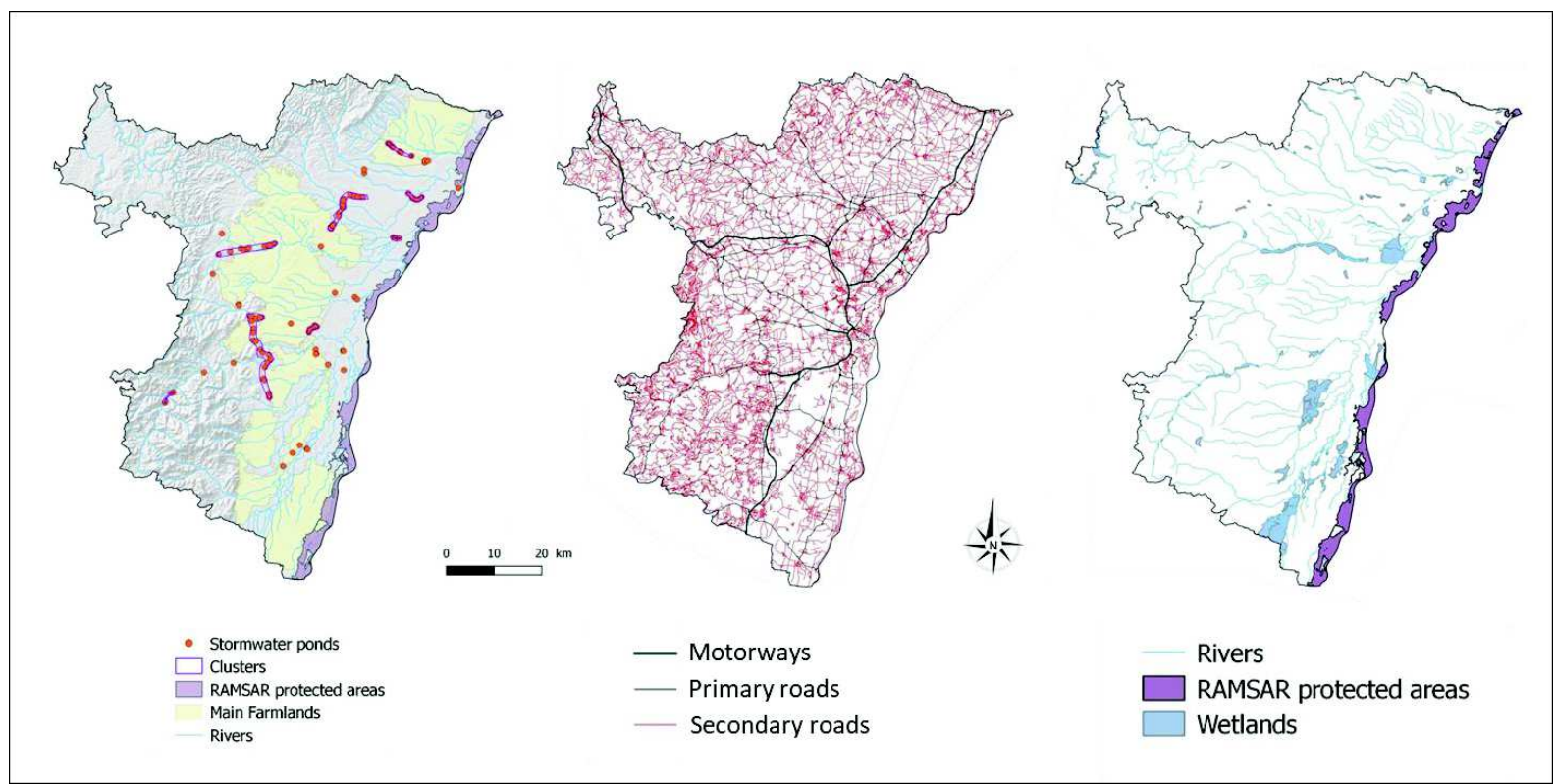

Figure 1: Bas-Rhin (Alsace, Eastern France). Map, left: location of studied stormwater ponds (orange). The stormwater ponds were grouped in clusters (purple), forming linear networks of ponds. Map, centre: motorways (wide black line), primary roads (thin black line) and secondary roads (red line) forming fragmented landscapes. Map, right: Location of wetlands (blue) and RAMSAR certified wetlands (purple). Most are located close to the Rhine river in the eastern part of the territory. 


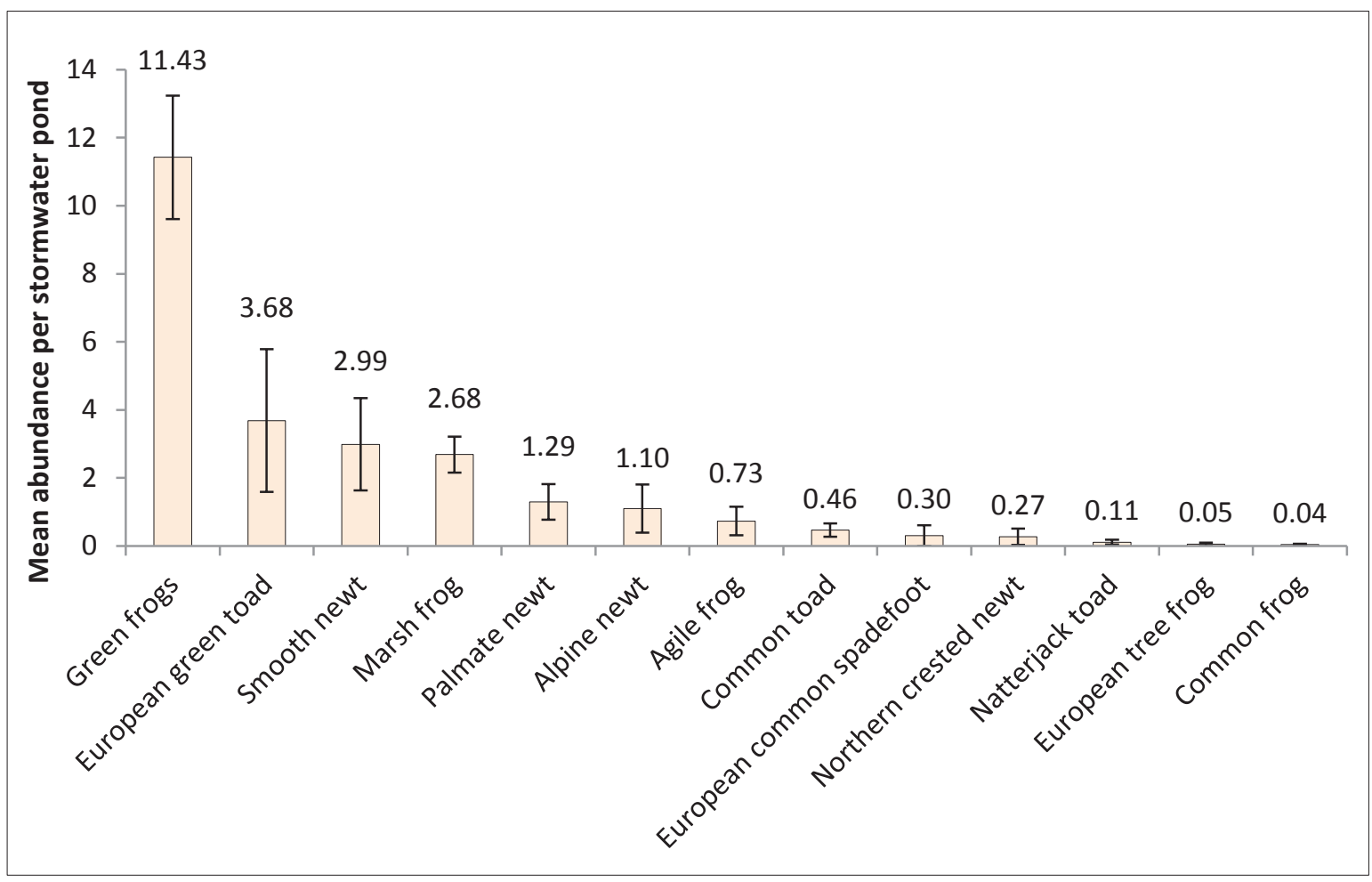

Figure 2: Specific mean abundances per stormwater pond. Error bars are standard error of the mean. Abundances are the maximal number of adult amphibians observed in a stormwater pond among the three field sessions for each species. Most observed species were Green frogs, European green toad, Smooth newt and Marsh frog. 


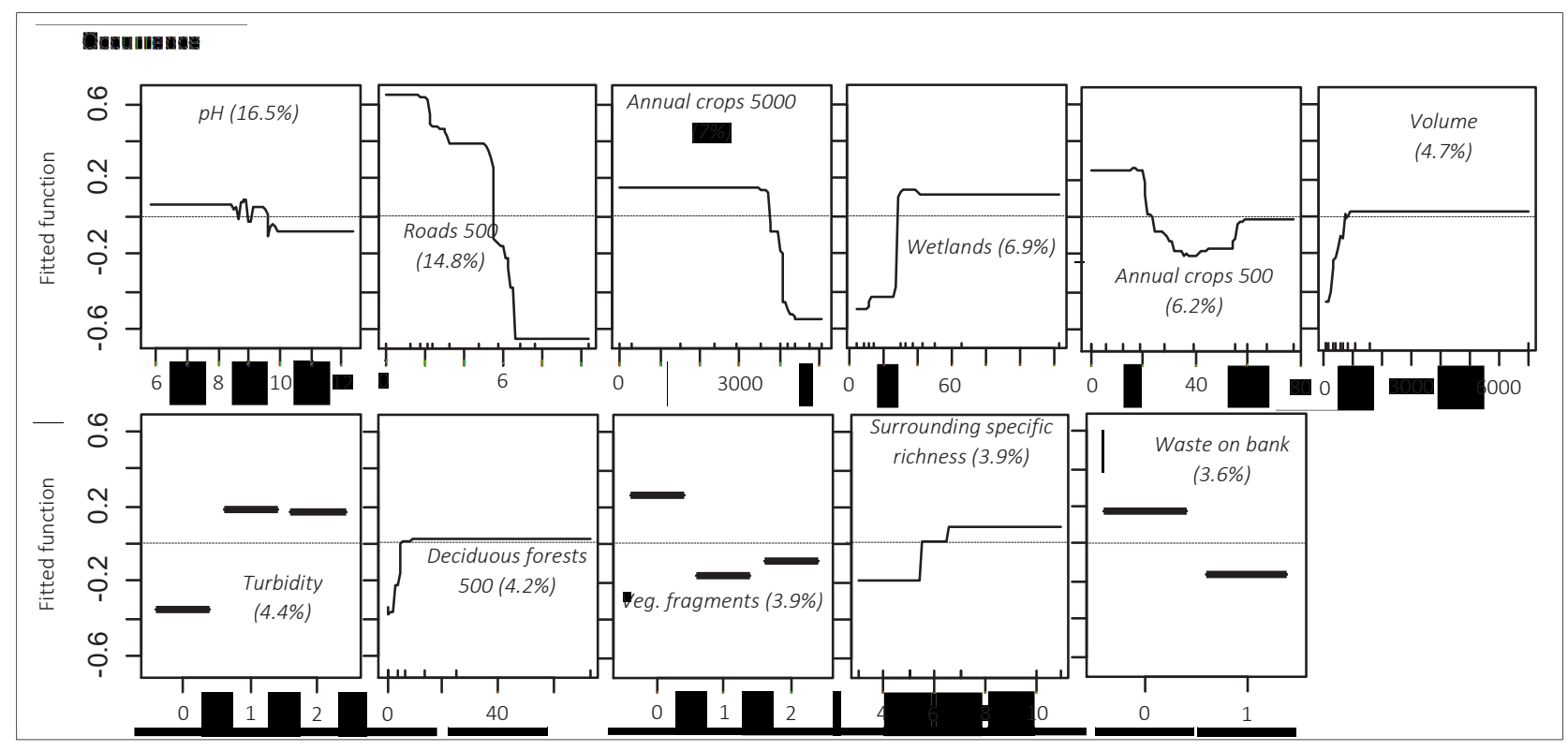

Figure 3: Fitted functions of factors with more than 3\% relative influence on the deviance of the global occurrence model. Meaning of factors lettering is in Tab.1. Basic $p H$, roads at local scale (presumably a barrier effect), and annual crops were the main factors having negative impacts on amphibian presence in stormwater ponds. Wetlands and ponds volume were the main positive ones. 


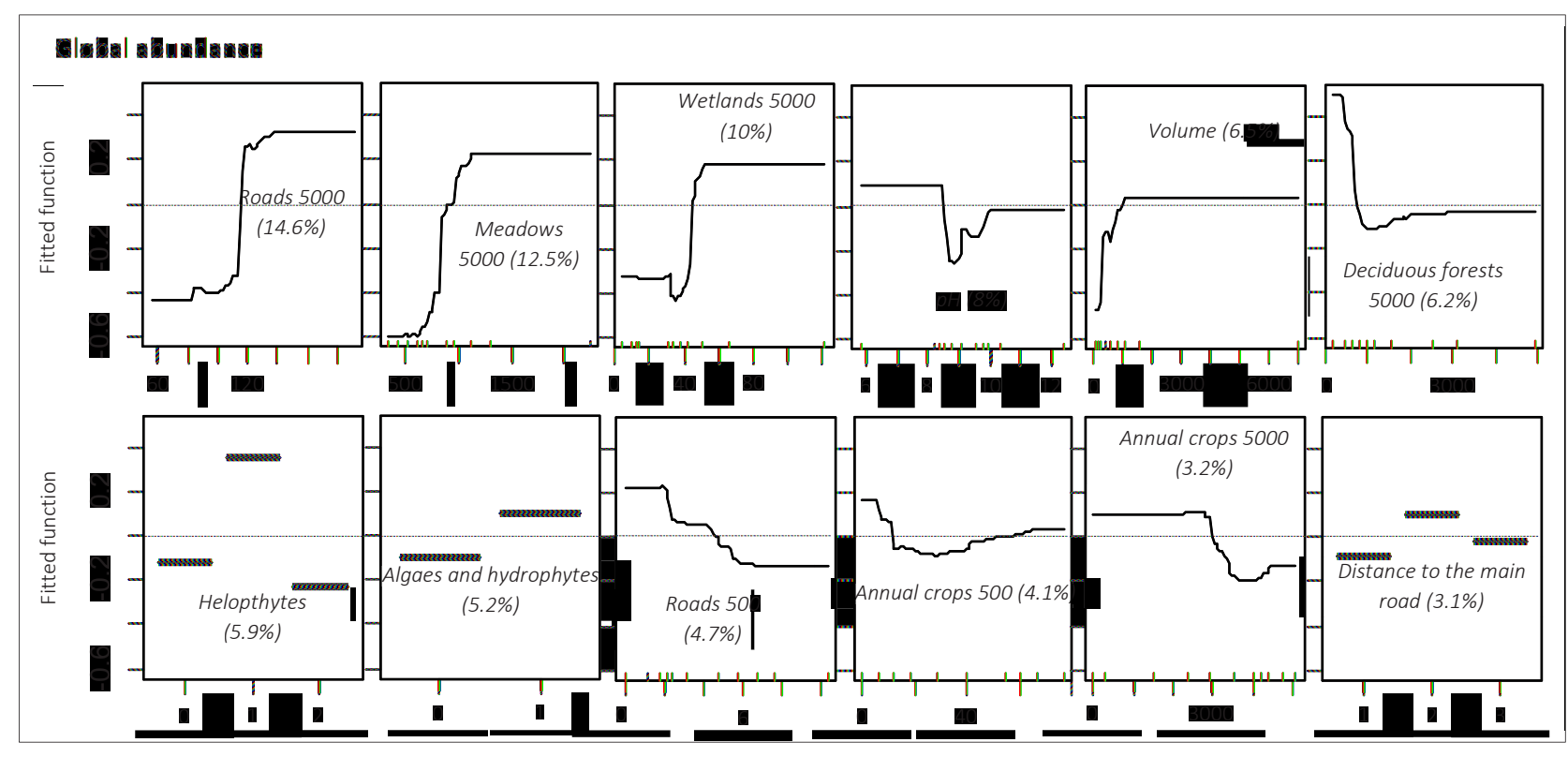

Figure 4: Fitted functions of factors with more than 3\% relative influence on the deviance of the global abundance model. Meaning of factors lettering is in Tab.1. Basic $\mathrm{pH}$ and surface of deciduous forests at large scale were the main factors having negative impacts on amphibian abundances in stormwater ponds. Road at large scale, meadows, wetlands and ponds volume were the main positive ones. 


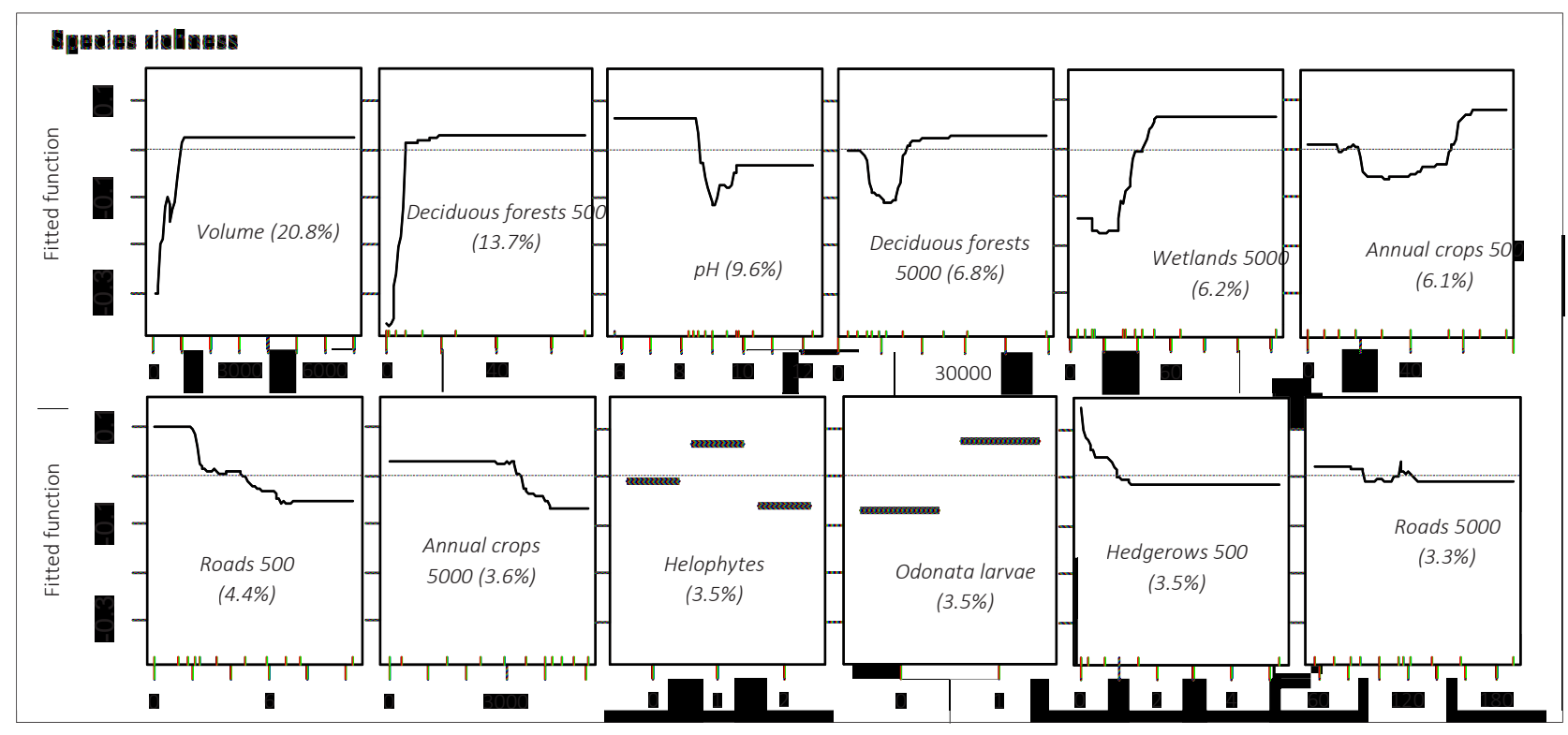

Figure 5: Fitted functions of factors with more than 3\% relative influence on the deviance of the species richness model. Meaning of factors lettering is in Tab.1. Basic $\mathrm{pH}$ and roads at local scale were the main factors having negative impacts on amphibian abundances in stormwater ponds. Ponds volume, deciduous forests, wetlands and annual crops (possible a refuge effect) were the main positive ones. 


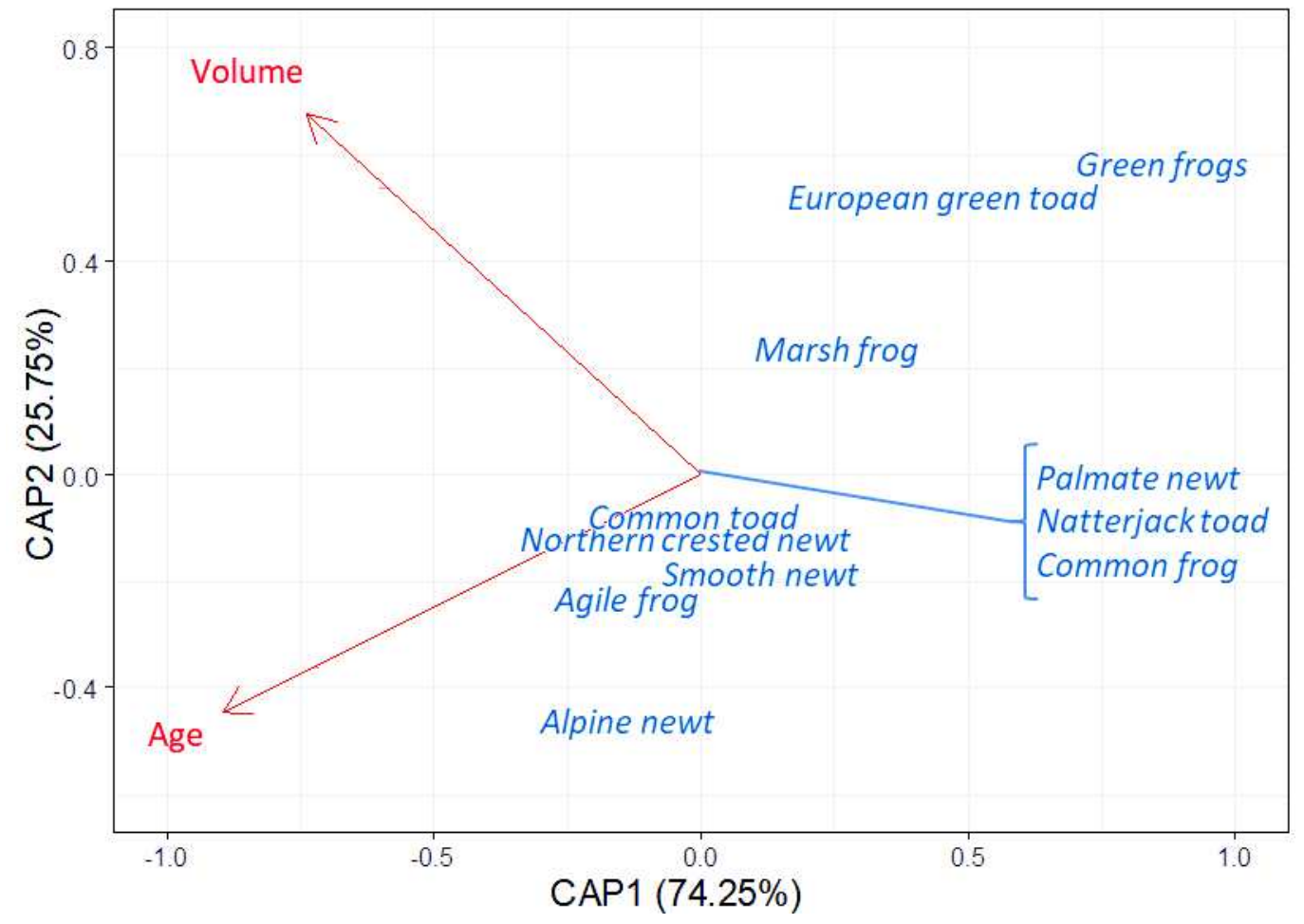

Figure 6: Correlation between species abundances (based on adults) and significant factors of Pond Design group. The abundance of a species whose name is located near the extremity of a factor is positively correlated with the factor. When the name is at the opposite, the correlation is negative. Greens frogs and the European green toad were more abundant in recent stormwater ponds and no clear species correlation was found with the pond volume. 


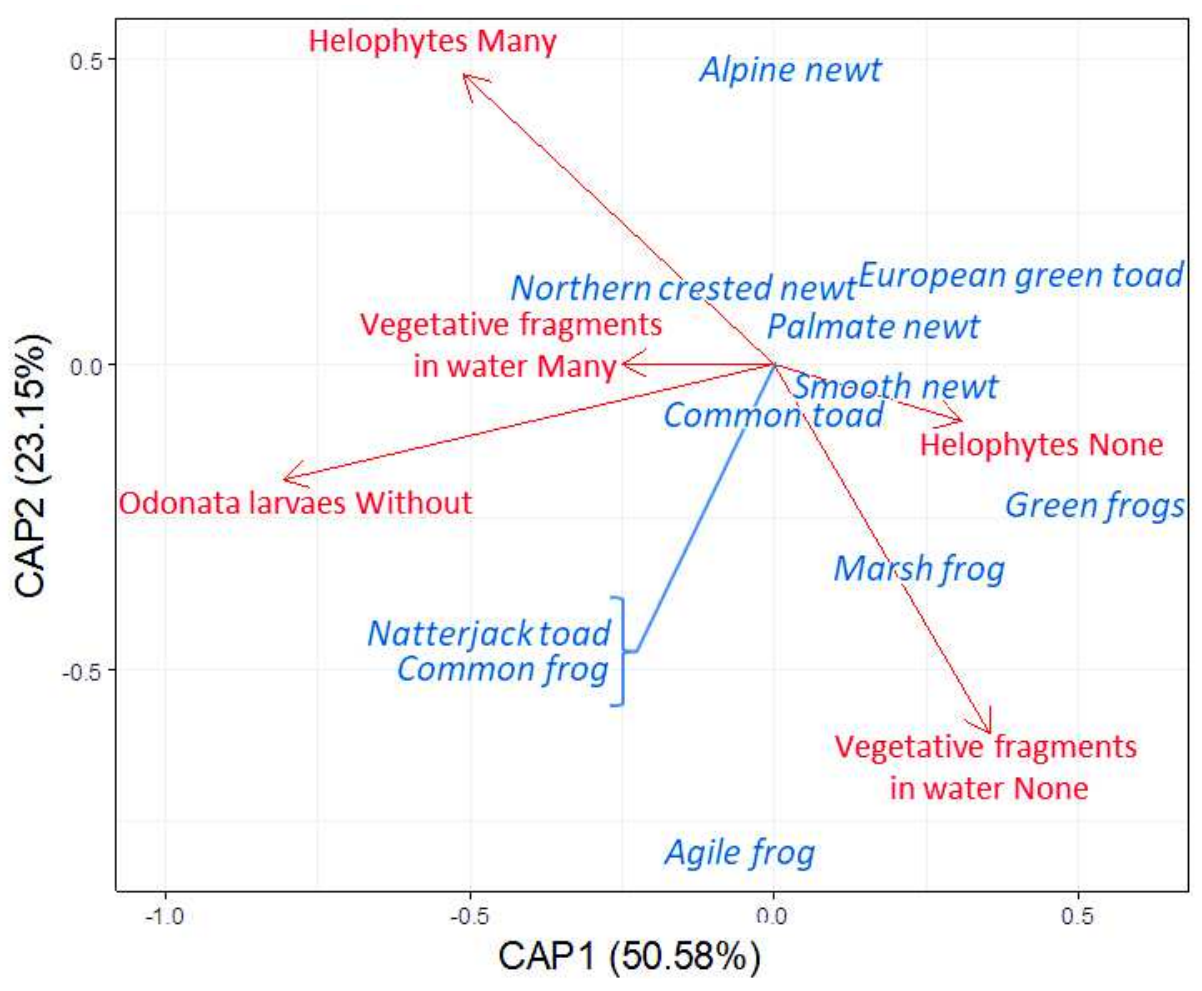

Figure 7: Correlation between species abundances (based on adults) and significant factors of Biotic factors group. The abundance of a species whose name is located near the extremity of a factor is positively correlated with the factor. When the name is at the opposite, the correlation is negative. Agile frog was more abundant when no vegetative fragments were present in ponds. Conversely, Alpine newt seemed to prefer ponds with many Helophytes. 


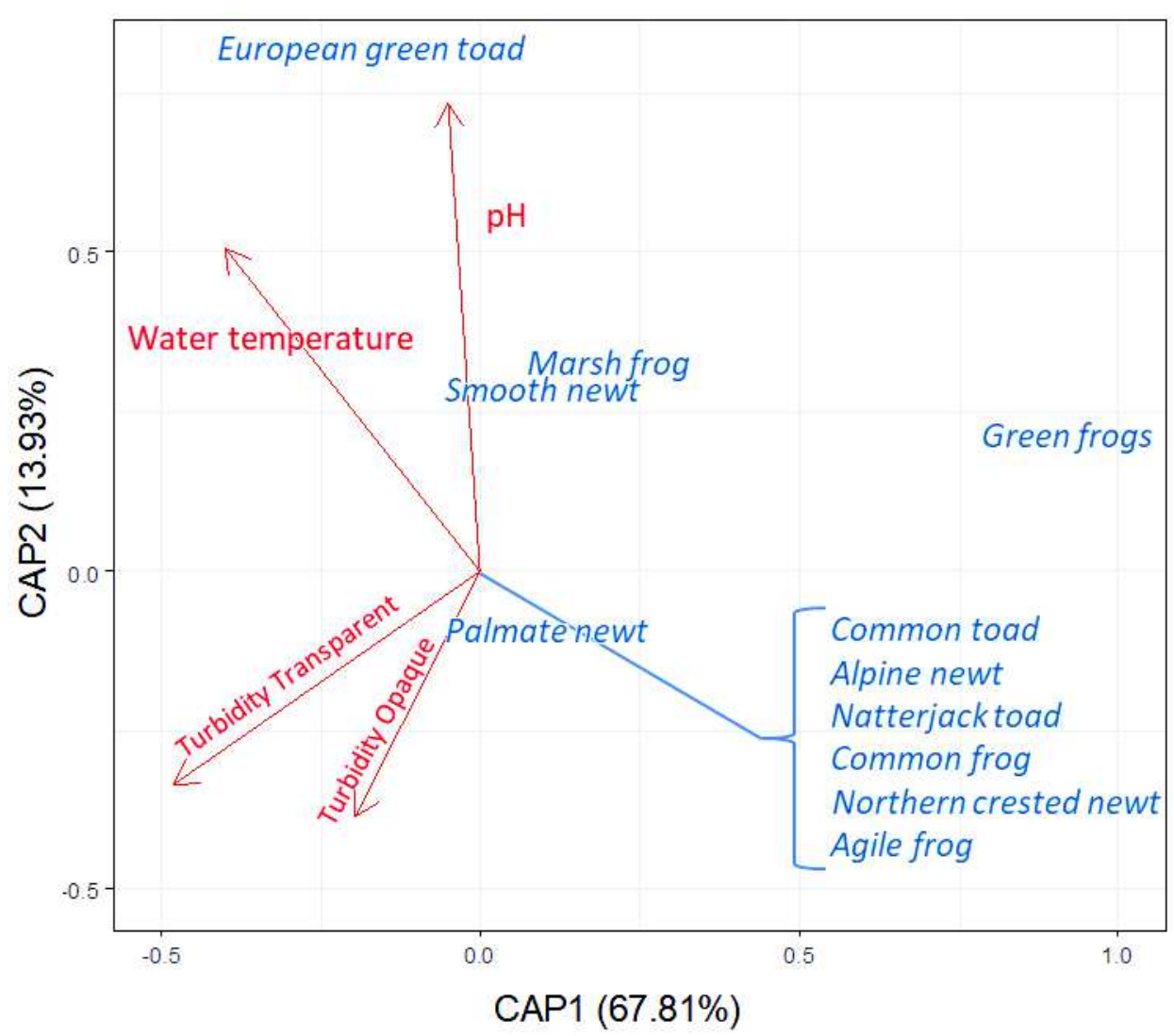

Figure 8: Correlation between species abundances (based on adults) and significant factors of immediate environmental factors group. The abundance of a species whose name is located near the extremity of a factor is positively correlated with the factor. When the name is at the opposite, the correlation is negative. The European green toad was more abundant in ponds with basic $\mathrm{pH}$ (note that $\mathrm{pH}$ range of ponds was 5.812.35 with a mean value of 9.05). 


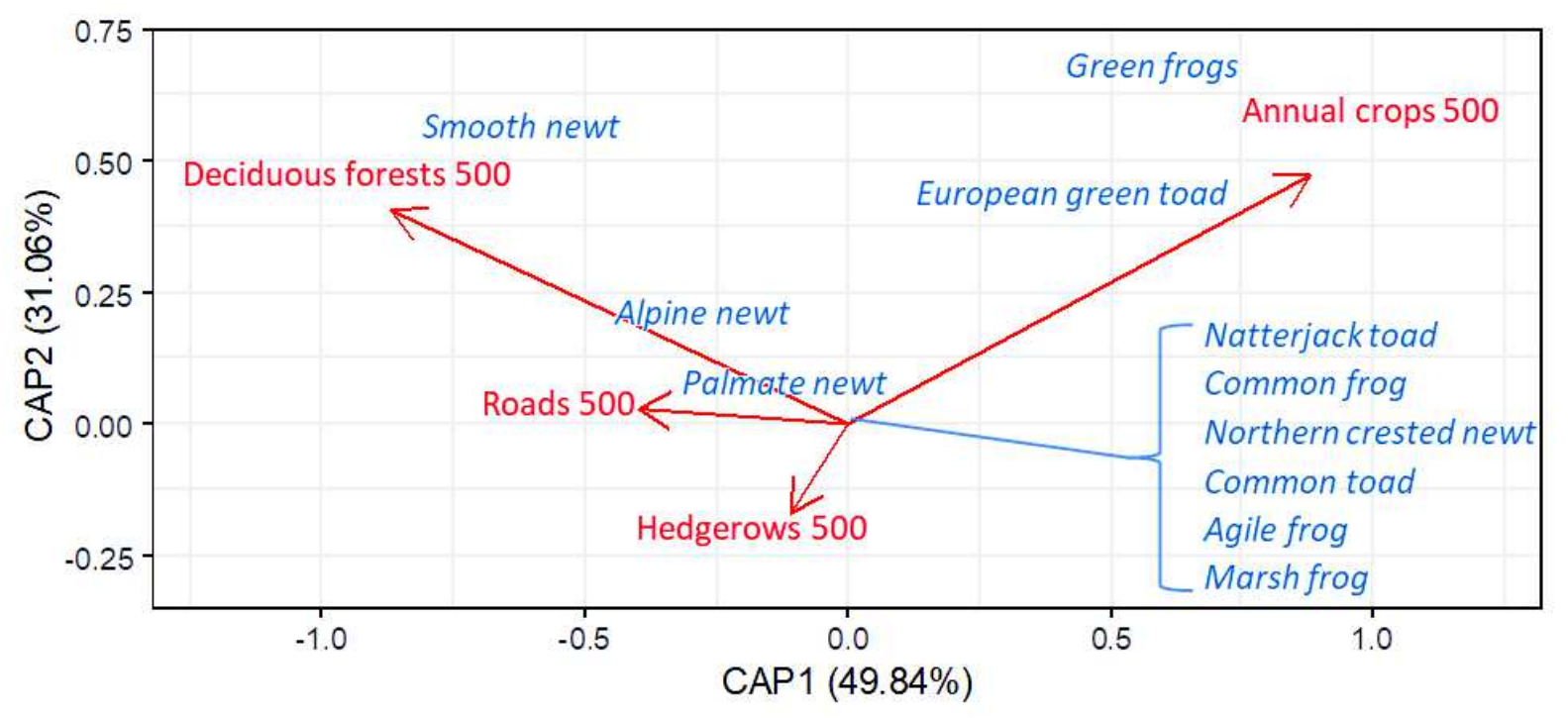

Figure 9: Correlation between species abundances (based on adults) and significant factors of Land use at Local scale group. The abundance of a species whose name is located near the extremity of a factor is positively correlated with the factor. When the name is at the opposite, the correlation is negative. Greens frogs and the European green toad were more abundant in stormwater ponds located in farmland whereas the Smooth newt was mainly present in stormwater ponds located in deciduous forests. 


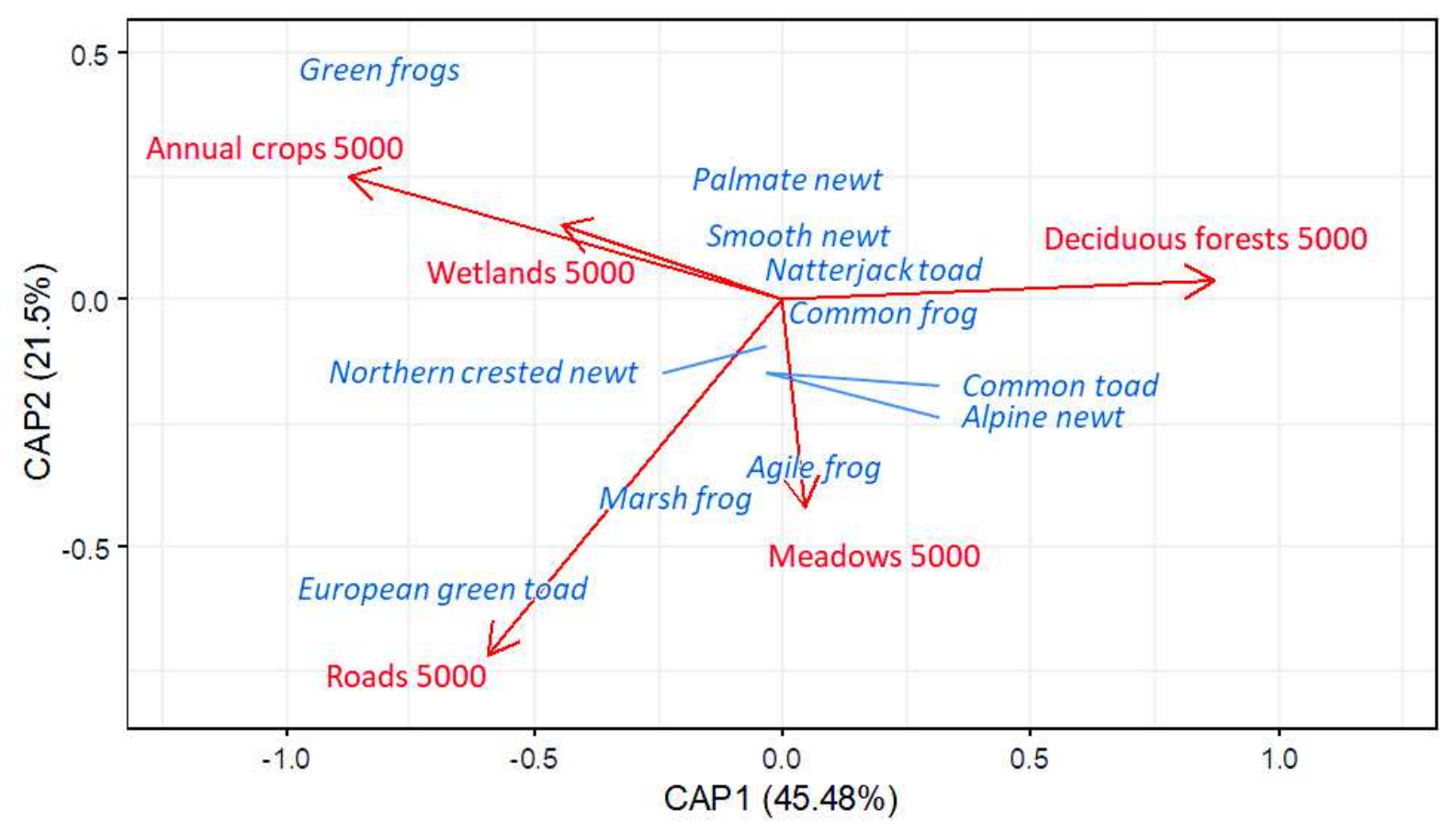

Figure 10: Correlation between species abundances (based on adults) and significant factors of Land use at Large scale group. The abundance of a species whose name is located near the extremity of a factor is positively correlated with the factor. When the name is at the opposite, the correlation is negative. Greens frogs and the European green toad were more abundant in stormwater ponds located in farmland whereas the Smooth newt was mainly present in stormwater ponds located in deciduous forests. 


\section{Tables}

Table 1: Description of factors used to explain variations of dependent variables. (a): factors which initially included more classes but were pooled due to low sample size; bold: factors with sufficient sample size that were retained after correlation analyses.

\begin{tabular}{|c|c|c|c|c|c|c|c|}
\hline Group & Factors & Min/class1 & Max/class2 & Median/class3 & $\begin{array}{c}\mathrm{IQ} \\
\text { range/class4 }\end{array}$ & Var. Type & $\begin{array}{l}\text { Measurement } \\
\text { type }\end{array}$ \\
\hline \multirow{20}{*}{$\begin{array}{l}\frac{c}{.00} \\
\frac{0}{\tilde{D}} \\
\frac{0}{0} \\
\frac{0}{0} \\
0 \\
0\end{array}$} & Volume $\left(\mathrm{m}^{3}\right)$ & 50 & 7000 & 539 & 667 & Quantitative & Data from \\
\hline & Depth (m) & 0.3 & 2.5 & 1 & 0,25 & Quantitative & $\begin{array}{l}\text { Data from } \\
\text { road manager }\end{array}$ \\
\hline & Age (y) & 0 & 35 & 8 & 15 & Quantitative & $\begin{array}{l}\text { Data from } \\
\text { road manager }\end{array}$ \\
\hline & Large fauna fence ( $12 \mathrm{~cm}$ mesh) & No & Yes & & & Qualitative & Visual \\
\hline & $\begin{array}{c}\text { Small fauna fence }(6.5 \mathrm{~mm} \\
\text { mesh) }\end{array}$ & No & $\begin{array}{l}\text { Yes, but without } \\
\text { bent top }\end{array}$ & Yes, with & ent top & Qualitative & Visual \\
\hline & Small fauna fence condition (a) & Intact & $1-2$ holes $>3 \mathrm{~cm}$ & $3+$ holes $>3 \mathrm{~cm}$ & & Qualitative & Visual \\
\hline & Service gate condition (a) & Intact & With holes $>3 \mathrm{~cm}$ & & & Qualitative & Visual \\
\hline & Cattle grid under service gate & No & Yes & & & Qualitative & Visual \\
\hline & Concrete wall & No & Yes & & & Qualitative & Visual \\
\hline & $\begin{array}{c}\text { Pond watertight- } \\
\text { ness/Permanent water }\end{array}$ & No & Yes & & & Qualitative & Visual \\
\hline & $\begin{array}{l}\text { Pond enclosure by } \\
\text { vegetation/stagnant water }\end{array}$ & No & Yes & & & Qualitative & Visual \\
\hline & Distance to the main road & $<3 \mathrm{~m}$ & $3-10 m$ & $>10 m$ & & Qualitative & $\begin{array}{c}\text { Laser } \\
\text { telemeter }\end{array}$ \\
\hline & Service bank & No & Yes & & & Qualitative & Visual \\
\hline & Length of banks & $<3 \mathrm{~m}$ & $>3 m$ & & & Qualitative & $\begin{array}{l}\text { Laser } \\
\text { telemeter }\end{array}$ \\
\hline & Bank soil & Natural & Artificial & & & Qualitative & Visual \\
\hline & Bank steepness (a) & Steep $(U)$ & Gentle (V) & & & Qualitative & Visual \\
\hline & $\begin{array}{l}\text { Hydrocarbon separator } \\
\text { (upstream) }\end{array}$ & No & Yes & & & Qualitative & Visual \\
\hline & $\begin{array}{l}\text { Hydrocarbon separator } \\
\text { (downstream) }\end{array}$ & No & Yes & & & Qualitative & Visual \\
\hline & Service ladder & No & Yes & & & Qualitative & Visual \\
\hline & Sunlight & Low & High & & & Qualitative & Visual \\
\hline \multirow{10}{*}{ 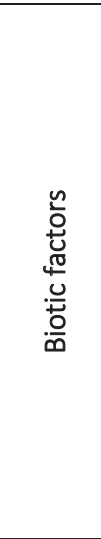 } & $\begin{array}{l}\text { Vegetative fragments in water } \\
\text { (as food) }\end{array}$ & None & Few & Many & & Qualitative & Visual \\
\hline & Branches (for fastening eggs) & None & Few & Many & & Qualitative & Visual \\
\hline & $\begin{array}{c}\text { Helophytes (for fastening eggs } \\
\text { and as shelters) }\end{array}$ & None & Few & Many & & Qualitative & Visual \\
\hline & Helophyte types & None & Phragmites & Molinia & Both & Qualitative & Visual \\
\hline & $\begin{array}{c}\text { Algae and hydrophytes (for } \\
\text { fastening eggs and as shelters) }\end{array}$ & None & Few & Many & & Qualitative & Visual \\
\hline & Odonata larvae (as predators) & No & Yes & & & Qualitative & Visual \\
\hline & $\begin{array}{l}\text { Leaves (for food and sunlight } \\
\text { reduction) }\end{array}$ & None & Few & Many & & Qualitative & Visual \\
\hline & Fishes (as predators) & No & Yes & & & Qualitative & Visual \\
\hline & Snakes (as predators) & No & Yes & & & Qualitative & Visual \\
\hline & Surrounding species richness & 3 & 11 & 5 & 2 & Quantitative & Odonat, 2017 \\
\hline \multirow{9}{*}{ 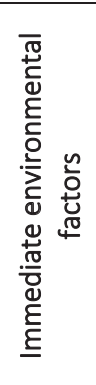 } & Waste on bank (a) & No & Yes & & & Qualitative & Visual \\
\hline & Waste on water (a) & No & Yes & & & Qualitative & Visual \\
\hline & $\begin{array}{l}\text { Luminosity (as visibility control) } \\
\qquad \text { (a) }\end{array}$ & $\begin{array}{l}\text { Low (has been } \\
\text { regrouped) }\end{array}$ & High & & & Qualitative & Visual \\
\hline & Rain (as visibility control) (a) & No & Yes & & & Qualitative & Visual \\
\hline & Wind (as visibility control) (a) & Low & High & & & Qualitative & Visual \\
\hline & Turbidity (as visibility control) & Transparent & Cloudy & Opaque & & Qualitative & Visual \\
\hline & HAP on surface $(a)$ & No & Yes & & & Qualitative & Visual \\
\hline & Visibility (as visibility control) & $<3 m$ & $3-10 m$ & $>10 m$ & & Qualitative & Visual \\
\hline & Air temperature $\left({ }^{\circ} \mathrm{C}\right)$ & 9 & 24 & 16 & 8 & Quantitative & thermometer \\
\hline
\end{tabular}




\begin{tabular}{|c|c|c|c|c|c|c|c|}
\hline & $\begin{array}{c}\text { Water temperature }\left({ }^{\circ} \mathrm{C}\right) \\
\mathrm{pH}\end{array}$ & $\begin{array}{l}11 \\
5.8\end{array}$ & $\begin{array}{r}19.5 \\
12.35\end{array}$ & $\begin{array}{c}16.33 \\
9.05\end{array}$ & $\begin{array}{c}2 \\
1,3\end{array}$ & $\begin{array}{l}\text { Quantitative } \\
\text { Quantitative }\end{array}$ & $\begin{array}{l}\text { thermometer } \\
\mathrm{pH} \text {-meter }\end{array}$ \\
\hline \multirow{15}{*}{ 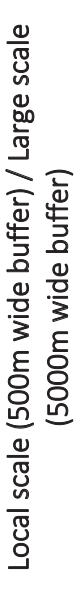 } & Hedgerows (ha) & $0 / 14.83$ & $5.28 / 96.72$ & $0.15 / 50.19$ & $0.84 / 18.65$ & Quantitative & SIG \\
\hline & Roads (ha) & 0 / 43.69 & 10.40 / 263.80 & 3.12 / 104.37 & 4.15 / 47.78 & Quantitative & SIG \\
\hline & Railways (ha) & $0 / 0$ & $3.63 / 177.49$ & $0 / 22.31$ & $0.54 / 23.48$ & Quantitative & SIG \\
\hline & Meadows (ha) & $0 / 329.77$ & $47.16 / 2538.59$ & 11.04 / 819.07 & 17.14 / 500.97 & Quantitative & SIG \\
\hline & Vines (ha) & $0 / 0$ & 35.50 / 1926.15 & $0 / 0$ & $0 / 5.46$ & Quantitative & SIG \\
\hline & Urban (ha) & $0 / 264.60$ & $65.90 / 3761.17$ & 9.32 / 929.51 & 18.69 / 659.77 & Quantitative & SIG \\
\hline & Plantations (ha) & $0 / 0$ & $6.00 / 274.36$ & $0 / 7.87$ & $0 / 31.01$ & Quantitative & SIG \\
\hline & Wetlands (ha) & $0 / 4.19$ & $5.20 / 125.11$ & $0 / 38.49$ & 1.49 / 43.77 & Quantitative & SIG \\
\hline & Grasslands (ha) & $0 / 0$ & 5.05 / 211.21 & $0 / 12.22$ & 0 / 23.21 & Quantitative & SIG \\
\hline & Moors (ha) & $0 / 0.96$ & $7.78 / 343.89$ & $0 / 28.42$ & $<0.01 / 59.01$ & Quantitative & SIG \\
\hline & Ponds (ha) & $0 / 0.55$ & 7.71 / 132.56 & $0 / 4.79$ & $0.10 / 7.06$ & Quantitative & SIG \\
\hline & Annual crops (ha) & $0 / 0$ & 77.26 / 6269.13 & $23.28 / 3223.69$ & $43.60 / 2188.04$ & Quantitative & SIG \\
\hline & Softwood forests (ha) & $0 / 0$ & $24.97 / 2816.30$ & $0 / 23.42$ & $0 / 271.32$ & Quantitative & SIG \\
\hline & Mixed forests (ha) & $0 / 0$ & 29.77 / 1759.29 & $0 / 64.57$ & $0 / 213.64$ & Quantitative & SIG \\
\hline & Deciduous forests (ha) & $0 / 80.92$ & $75.23 / 4925.78$ & $0.81 / 1128.07$ & $10.90 / 1066.59$ & Quantitative & SIG \\
\hline \multirow{21}{*}{ 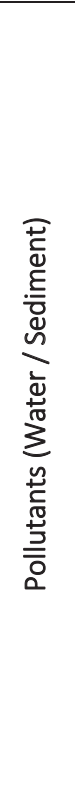 } & $(\mu \mathrm{S} / \mathrm{cm})$ Conductivity & $64 /-$ & $937 /-$ & 162.6/ - & 140.8/ - & Quantitative & See Tab SM \\
\hline & (mg/l) Salinity & $0 /-$ & $420 /-$ & $0 /-$ & $127.92 /-$ & Quantitative & See Tab SM \\
\hline & $\mathrm{pH}$ & $5.8 /-$ & $12.35 /-$ & $9.05 /-$ & $1.3 /-$ & Quantitative & See Tab SM \\
\hline & (mg/l) Chloride & $1.7 /-$ & 107.6/ - & $8.9 /-$ & 15.6/ - & Quantitative & See Tab SM \\
\hline & (mg/l) Suspended materials & $0 /-$ & $260 /-$ & $11.45 /-$ & 19.07/ - & Quantitative & See Tab SM \\
\hline & (mg/l) Nitrates & $0 /-$ & $21.3 /-$ & $0.77 /-$ & $1.25 /-$ & Quantitative & See Tab SM \\
\hline & (mg/l) Nitrites & $0 /-$ & $0.21 /-$ & $0.03 /-$ & $0.07 /-$ & Quantitative & See Tab SM \\
\hline & (mg/l) PAH (mg/kgMS) & $0 / 0.07 /-$ & $0.68 / 15.51$ & $0 / 0.53 /-$ & $0 / 10.90$ & Quantitative & See Tab SM \\
\hline & (mg/l) Phosphorus & $0 /-$ & $0.4 /-$ & $0 /-$ & $0.1 /-$ & Quantitative & See Tab SM \\
\hline & (mg/l) Mercury (mg/kgMS) & $0 / 0.01$ & $0 / 0.34$ & $0 / 0.13$ & $0 / 0.06$ & Quantitative & See Tab SM \\
\hline & ( $\mathrm{gg} / \mathrm{l})$ Arsenic (mg/kgMS) & $0 /<0.01$ & $6.7 / 16.4$ & $0.7 / 7.70$ & $1.39 / 8.99$ & Quantitative & See Tab SM \\
\hline & ( $\mu \mathrm{g} / \mathrm{l})$ Cadmium (mg/kgMS) & $0 /<0.01$ & $0.02 / 95$ & $<0.01 / 0.5$ & $<0.01 / 0.9$ & Quantitative & See Tab SM \\
\hline & ( $\mu \mathrm{g} / \mathrm{l})$ Chromium (mg/kgMS) & 0 / 0.1 & $18 / 95$ & $1.67 / 41.6$ & 1.32 / 69.6 & Quantitative & See Tab SM \\
\hline & ( $\mu \mathrm{g} / \mathrm{l})$ Copper (mg/kgMS) & $1.1 /<0.01$ & $23.1 / 390$ & $6.77 / 84.5$ & $6.27 / 212.5$ & Quantitative & See Tab SM \\
\hline & ( $\mu \mathrm{g} / \mathrm{l})$ Nickel (mg/kgMS) & $0 / 0.1$ & $13.4 / 45.4$ & $0 / 20.6$ & $0 / 29$ & Quantitative & See Tab SM \\
\hline & ( $\mu \mathrm{g} / \mathrm{l})$ Lead (mg/kgMS) & $0 / 0.12$ & $16.9 / 118$ & $0.74 / 40$ & $1.7 / 69.70$ & Quantitative & See Tab SM \\
\hline & $(\mu \mathrm{g} / \mathrm{l})$ Zinc $(\mathrm{mg} / \mathrm{kgMS})$ & $0 / 0.2$ & $99 / 3085.2$ & $25.5 / 685.4$ & $25.25 / 1214.2$ & Quantitative & See Tab SM \\
\hline & Fluoranthene ( $\mu \mathrm{g} / \mathrm{kgMS})$ & $-/ 0.05$ & $-/ 1748$ & $-/ 1.682$ & $-/ 414.42$ & Quantitative & See Tab SM \\
\hline & Benzo(b)fluoranthene ( $\mu \mathrm{g} / \mathrm{kgMS}$ ) & $-/ 0.06$ & $-/ 913$ & $-/ 1.37$ & $-/ 235.01$ & Quantitative & See Tab SM \\
\hline & Benzo(a)pyrene ( $\mu \mathrm{g} / \mathrm{kgMS})$ & $-/ 0.05$ & $-/ 793$ & $-/ 23$ & $-/ 228.78$ & Quantitative & See Tab SM \\
\hline & Sum 7 PCB $(\mu \mathrm{g} / \mathrm{kgMS})$ & $-/ 0.04$ & $-/ 29.5$ & $-/ 0.10$ & $-/ 0.01$ & Quantitative & See Tab SM \\
\hline
\end{tabular}


Table 2: Relative influences of significant factors on deviance in each model. In line one, the $\mathrm{pH}$ explained $16.55 \%$ of variations of the global occurrence model, which itself explained $64 \%$ of the variation of the global occurrence. Landscape element factors explained 56\% of the summed relative influences.

\begin{tabular}{|c|c|c|c|c|}
\hline \multirow[b]{2}{*}{ Factor } & \multicolumn{4}{|c|}{ Relative influence (\%) } \\
\hline & $\begin{array}{c}\text { Global } \\
\text { Occurrence } \\
D^{2}=0.64\end{array}$ & $\begin{array}{c}\text { Global } \\
\text { Abundance } \\
\mathrm{D}^{2}=0.76\end{array}$ & $\begin{array}{l}\text { Species } \\
\text { richness } \\
D^{2}=0.54\end{array}$ & $\begin{array}{c}\text { Sum of } \\
\text { relative } \\
\text { influence (\%) }\end{array}$ \\
\hline $\mathrm{pH}$ & 16.55 & 8.05 & 9.56 & 34.15 \\
\hline Volume $\left(\mathrm{m}^{3}\right)$ & 4.44 & 6.53 & 20.83 & 31.81 \\
\hline Roads $500\left(\mathrm{~m}^{2}\right)$ & 14.81 & 4.66 & 4.37 & 23.84 \\
\hline Wetlands $5000\left(\mathrm{~m}^{2}\right)$ & 6.94 & 10.02 & 6.24 & 23.20 \\
\hline $\begin{array}{c}\text { Deciduous forests } 500\left(\mathrm{~m}^{2}\right) \text { (c.t. Mixed and Softwood } \\
\text { forest) }\end{array}$ & 4.17 & 2.64 & 13.73 & 20.54 \\
\hline Roads $5000\left(\mathrm{~m}^{2}\right)$ & 2.18 & 14.57 & 3.30 & 20.04 \\
\hline Annual crops $500\left(\mathrm{~m}^{2}\right)$ (Meadows, Urban) & i.e. 6.26 & 4.06 & 6.05 & 16.37 \\
\hline $\begin{array}{c}\text { Deciduous forests } 5000\left(\mathrm{~m}^{2}\right) \text { (i.e. Mixed and Softwood } \\
\text { forest) }\end{array}$ & 1.87 & 6.22 & 6.83 & 14.92 \\
\hline Annual crops $5000\left(\mathrm{~m}^{2}\right)$ (i.e. vines, copses) & 6.96 & 3.21 & 3.57 & 13.73 \\
\hline Meadows $5000\left(\mathrm{~m}^{2}\right)$ & 1.08 & 12.46 & 0 & 13.54 \\
\hline Helophytes (to fix eggs to branches and as shelters) & 1.87 & 5.93 & 3.54 & 11.34 \\
\hline $\begin{array}{l}\text { Algae and hydrophytes (to fix eggs to branches and as } \\
\text { shelters) }\end{array}$ & 2.85 & 5.17 & 0 & 8.02 \\
\hline Water temperature $\left({ }^{\circ} \mathrm{C}\right)$ (i.e. Air temperature) & 2.87 & 2.12 & 2.71 & 7.70 \\
\hline Odonata larvae (as predators) & 2.65 & 1.39 & 3.54 & 7.58 \\
\hline Hedgerows $500\left(\mathrm{~m}^{2}\right)$ & 2.10 & 1.76 & 3.52 & 7.38 \\
\hline Age (y) & 1.45 & 2.52 & 2.99 & 6.95 \\
\hline Surrounding species richness & 3.85 & 0.62 & 1.77 & 6.24 \\
\hline Vegetative fragments in water (as food) & 3.87 & 0 & 2.00 & 5.87 \\
\hline Hedgerows $500\left(\mathrm{~m}^{2}\right)$ & 2.10 & 0 & 3.52 & 5.62 \\
\hline Surrounding species richness & 3.85 & 0 & 1.77 & 5.62 \\
\hline
\end{tabular}

